\title{
"JÁ QUE A DESGRAÇA ASSIM QUERIA" UM \\ FEITICEIRO FOI SACRIFICADO: \\ CURANDEIRISMO, ETNICIDADE E HIERARQUIAS SOCIAIS \\ (PELOTAS - RS, 1879)
}

\author{
Paulo Roberto Staudt Moreira* \\ Caiuá Cardoso Al-Alam**
}

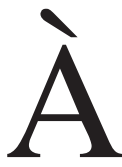

s 10 da manhã do dia 15 de janeiro de 1879 , numa quarta-feira, o movimento deveria ser intenso no centro da cidade de Pelotas, na província de São Pedro do Rio Grande do Sul. Talvez para fugir do calor, o negociante e carreteiro uruguaio Manoel Roxo, 60 anos, casado, trabalhava no escritório de sua casa de comércio, na rua Vinte e Quatro de Outubro quando ouviu gritos aflitivos. ${ }^{1}$

Roxo foi até a porta da rua ver o que ocorria e viu o preto liberto Tomás Soares jogado na sarjeta, junto da calçada "e o agredindo um cachorro da terra nova". Sobre o liberto, Roxo viu o escravo Antonio fazendo movimentos com o braço e a mão, que ele interpretou como sendo para desvencilhar Tomás do ataque canino. ${ }^{2}$ A interpretação errô-

\footnotetext{
Professor do Programa de Pós-Graduação em História da UNISINOS. staudt@ unisinos.br

** Professor da Universidade Federal do Pampa, campus Jaguarão. caiuaalam @ gmail.com

1 Processo crime, 1879, Arquivo Público do Estado do Rio Grande do Sul (APERS), Vara Cível e Crime de Pelotas, processo no 261, maço 261.

2 A referência a este personagem canino aparece também na quarta testemunha arrolada, Guilherme Bertel (de 33 anos, casado, entalhador e morador em Pelotas). O alemão Bertel contou que ouviu gritos e saindo de sua casa, na rua 24 de Outubro, viu um negro deitado no chão e um cachorro Terra Nova "que sacudia o dito preto pelo pescoço", e o acusado que fugia com um cacete numa mão e uma faca na outra. O cachorro logo largou o preto, que galgou a calçada, se encostou na parede e caiu morto, segurando a barriga. A dramaticidade da presença desse cão nesses dois depoimentos se contrapõe a absoluta ausência da menção ao mesmo nos demais interrogados. Mesmo que pareça existir uma clara distinção entre o cão e o ofendido, não nos escapa que pode tratar-se de uma metáfora, com as testemunhas mencionando pejorativamente o réu, por sua afro descendência.
} 
nea inicial se desvaneceu quando Roxo viu Tomás levantar apertando a barriga com as mãos, soltando gritos de dor subiu a calçada e caiu ao solo. Enquanto isso, o escravo Antonio se retirava precipitadamente, levando na mão direita uma faca ensanguentada e na mão esquerda um cacete.

O proprietário Francisco Fagundes de Oliveira, casado, de 56 anos, presenciou todo o ocorrido. Ele viu o preto Tomás correndo e o escravo Antonio perseguindo-o logo atrás e, percebendo que o "negócio era de morte", gritou-lhe que "largasse a faca e não ferisse o outro". Sem ouvir os clamores, Antonio aproveitou que sua vítima caiu e deulhe três facadas "com muita destreza e pondo a faca na bainha com muita facilidade deitou a disparar". Fagundes ainda gritou "para-te negro" e alertou um homem que passava a cavalo para que perseguisse e prendesse o criminoso. O cavaleiro era o negociante português Francisco dos Santos Correia, 29 anos, solteiro, que de sua residência no Passo dos Negros vinha ao centro da cidade e testemunhou todo o ocorrido, disparando com sua montaria em perseguição ao homicida. ${ }^{3}$

A rua do delito, a 24 de Outubro, é a atual Tiradentes, localizada no centro administrativo e comercial da cidade, próxima ao Paço Municipal e ao Mercado Público. O escravo Antonio, ao que parece deliberadamente, depois de esfaquear o liberto africano Tomás, embainhou o seu instrumento de trabalho e de desgraça e correu, perseguido por várias pessoas aos gritos de pega, pega, até entregar-se ao subdelegado de Polícia Antonio José Rodrigues de Araújo, minutos após cometer o crime.

O promotor público Francisco Luiz Osório, após ouvir as testemunhas e examinar o documento firmado pelos peritos, considerou o réu Antonio incurso no crime de homicídio, artigo 193 do Código Criminal, com as circunstâncias agravantes do artigo 16 parágrafo $4^{\circ}$ e $6^{\circ}$ do citado código, ou seja, "ter sido o delinquente impelido por um motivo reprovado, ou frívolo" e "haver no delinquente superioridade em sexo, forças, ou armas, de maneira que o ofendido não pudesse defender-se com probabilidade de repelir a ofensa".

O Passo dos Negros, localizado próximo ao arroio Pelotas, à beira do canal São Gonçalo, ficou conhecido assim pelo intenso movimento de trabalhadores escravos que por ali entravam e eram comercializados principalmente para as charqueadas. Também foi conhecido como Passo Rico e Passo das Neves; Caiuá Cardoso Al-Alam, "Passo dos Negros", in Beatriz Ana Loner, Lorena Almeida Gill, Mario Osório Magalhães (orgs.), Dicionário de História de Pelotas (Pelotas: Editora da UFPel, 2010), pp. 192-3. 
No mesmo dia em que Antonio cumpriu a sua desgraçada sina, 15 de janeiro de 1879, ele deu o seu primeiro depoimento acerca do ocorrido. Ao longo do processo crime montado, Antonio foi quatro vezes interrogado e manteve uma mesma versão, sem grandes modificações. Disse chamar-se Antonio, não sabia a idade, mas seus algozes diziam que ele representava ter 40 anos mais ou menos, era viúvo, natural de Pernambuco, filho do preto forro Luiz e da escrava Catarina, analfabeto, escravo de Joaquim Rasgado, em cuja charqueada trabalhava há uns dez anos mais ou menos. Na primeira vez em que conversou com as autoridades Antonio disse ser cozinheiro, mas nas três vezes seguintes corrigiu para cozinheiro e carneador. Transcrevemos abaixo o primeiro depoimento de Antonio que, mesmo que longo, dará uma boa ideia do drama que cercava aquele acontecimento fatídico:

[...] respondeu que sendo carneador na charqueada de seu senhor, é muitas vezes castigado com açoites por cortar o couro das reses que carneia, e este castigo é feito pelo administrador da charqueada, por nome Serafim Pelado, que anteontem tendo cortado um couro, e receando ser de novo castigado, saiu da charqueada e veio apadrinhar-se com Joaquim Assumpção, Dr. Gama Lobo e Leonardo Honório da Silva, e todos eles o mandaram apadrinhado; que chegando na charqueada o administrador Serafim não o castigou, porém batendo-lhe no ombro, disse: não faz mal, daqui a dois ou três dias estas pegado; que ontem estando carneando, teve ainda a infelicidade de cortar um couro, perto da cola junto a garra, e tendo medo de apanhar; e lembrando-se do que dissera o administrador, fugiu da charqueada e veio apadrinhar-se com o Dr. Barcelos e Dr. Abreu, porem ambos lhe disseram que não se dando com seu senhor não o podiam apadrinhar; que então ele interrogado vendo-se sem proteção, lembrou-se que a três meses mais ou menos, tinha pago três mil reis ao preto forro Tomás, ex-escravo de Manoel Bernardino Soares, para que ele, que se dizia feiticeiro, fizesse com que o administrador e capataz da charqueada de seu senhor não o castigasse tantas vezes, porem vendo que o feitiço prometido por Tomás não produzia o efeito desejado, resolveu hoje ir procurar a Tomás em sua casa e fazer com que ele lhe devolvesse os três mil réis, e caso o não fizesse o mataria, visto não poder matar como desejava o administrador Serafim, o capataz Joaquim Pereira; que com efeito encontrou Tomás em uma casa a rua Vinte Quatro de Outubro, junto a fabrica de Carlos Ruel, e pedindolhe os três mil réis referidos, Tomás disse-lhe que agora não tinha, e que ia dizer ao senhor deste interrogado que este queria que ele fizesse fei- 
tiço; que nesta conversa vieram pela mesma rua acima até a venda de Roberto de Tal, aonde entraram e tomaram cachaça, que foi paga por Tomás; que saindo da venda, em direção ao mercado, Tomás continuou a negar-lhe o pagamento dos três mil réis e também a descompô-lo chamando-o até de ladrão, então ele interrogado que já andava com a cabeça incomodada por seu cativeiro, puxou da faca que trazia oculta dentro do colete, e cravou-a três vezes em Tomás, sendo uma facada no peito, e duas na barriga; que desde que viu Tomás cair com os ferimentos por ele feito, veio apresentar-se ao Dr. Delegado de Policia, para ser preso, trazendo ainda a faca tinta do sangue de Tomás, que entregou a autoridade e é a mesma que neste ato lhe é apresentada. Disse mais que, como já declarou, a sua intenção era matar o administrador ou o capataz da charqueada de seu senhor, porém como não pôde satisfazer a sua vontade, mister porque eles não se descuidavam com ele interrogado, então ele interrogado entendeu que Tomás deveria ser o sacrificado, já que a desgraça assim queria.

Casos coletados das páginas de documentos judiciários envolvendo feiticeiros são ótimos observatórios da sociedade escravista em sua miudeza relacional. Principalmente em processos criminais, os feiticeiros (ou curandeiros) são não raramente personagens centrais, constando como réus ou ofendidos de assassinados, ferimentos, suspeitos da prática de homicídio, incursos nos crimes de roubo ou furto, fomentadores de insurreições. Outras vezes eles se materializam como personagens fugidios, pouso ou ponto de passagem dos atores principais, quase figurantes, cuja existência ilumina a cena. O contato (ou embate) entre Antonio e Tomás nas ruas centrais da Pelotas oitocentista legounos um documento judiciário precioso, que pode nos auxiliar a remontar o campo de possibilidades relacionais no qual estavam inseridos ativamente os cativos, mesmo que de estabelecimentos penitenciários como as charqueadas. Além disso, essa pista judiciária nos permite uma aproximação com o mercado da crença e o papel dos feiticeiros/curandeiros na sociabilidade e conformação de identidades etnicosociais.

\section{A Pelotas oitocentista}

Em diálogo com a produção historiográfica nacional, muito se tem pesquisado sobre escravidão tomando como lócus Pelotas e seu entorno. Foi-se o tempo em que a cidade e os indivíduos subjugados a este 
sistema de trabalho eram vistos de forma passiva, sem racionalidade própria, frutos apenas das intenções dos seus senhores. ${ }^{4}$

Esta historiografia que hoje se detém naquela localidade tem evidenciado as múltilpas formas de experiência de vida daqueles homens e mulheres que, no final do século XIX, vivenciavam uma cidade que crescia, que atraía cada vez mais pessoas em busca de enriquecimento e de oportunidades de trabalho. ${ }^{5}$ Pessoas que não compunham apenas setores das elites charqueadoras, mas outras que abasteciam os mercados periféricos a esta grande produção. ${ }^{6}$

A cidade se insere no que hoje se conhece como "história transatlântica", ou seja, sua proximidade com o porto de Rio Grande possibilitava um contato fundamental com o mundo material e das ideias do Atlântico. Octacilio Camará, em livro publicado no ano de 1887, que defendia o valor estratégico da cidade "por sua posição geográfica, topográfica e vantagens hidrográficas", escrevia:

Realmente, é Pelotas o ponto que mais pronta e eficazmente pode socorrer com recursos vindos de barra fora as fronteiras de Chui, Jaguarão, Bagé, Santana do Livramento e Quarai, quer por via terrestre, quer por navegação fluvial, como provaremos adiante numericamente.

E qual a localidade da Província que, como Pelotas, possa facilmente prestar imediato auxilio, incessantemente renovado, a cinco fronteiras? Nenhuma outra!

Importante rota comercial, a mobilidade de pessoas na região foi vista como problemática para as autoridades policiais, pois trazia consigo algo mais poderoso ainda do que o tão temido ajuntamento de es-

4 Ver: Fernando Henrique Cardoso, Capitalismo e escravidão no Brasil meridional. O negro na sociedade escravocrata do Rio Grande do Sul, Rio de Janeiro: Paz e Terra, 1977.

5 No censo de 1872 foram registradas 21.258 pessoas e em 1890, 37.256 pessoas. Ver: Beatriz Loner, Construção de classe: operários de Pelotas e Rio Grande (1888-1930), Pelotas: Universitária, 2001, p. 69; Ester Gutierrez, Barro e sangue: mão-de-obra, arquitetura e urbanismo em Pelotas (1777-1888), Pelotas: Universitária, 2004, p. 498.

6 Em 1861, a produção relacionada às charqueadas ocupava 74,9\% do que produzia a Província, em 1894 houve um declínio para 42,2\%; Jefferson Marçal da Rocha, As raízes do declínio econômico da "Metade Sul" do Rio Grande do Sul - uma análise da racionalidade econômica dos agentes produtivos da região, Primeiras Jornadas de História Regional Comparada. POA: 2000, p. 8. Disponível em: www.fee.tche.br/sitefee/download/jornadas/1/s12a5.pdf, acesso no dia 12 de junho de 2009.

7 Octacilio Camará, Valor estrategico da cidade de Pelotas. Novo plano geral de defesa da Província do Rio Grande do Sul e vantagens agricolo-commerciaes que delle resultam. Pelotas/ Porto Alegre/Rio Grande: Livraria Americana, 1887. 
cravos na região das charqueadas: a possibilidade do diálogo entre o mundo dos escravos e o dos livres. Muitos são os registros que demonstram esta preocupação, como o ofício enviado pela Câmara ao presidente da província em 1873, que justificava a reivindicação de um batalhão do Exército na cidade pelo "grande número de pessoas estranhas e de todas as classes da sociedade, que diariamente entram da campanha e Estado Oriental, principalmente nesta época de trabalhos das charqueadas", finalizando com uma ênfase no "grande número de escravos existente nesta cidade e circunvizinhanças". 8

Zona de contato de diversas línguas e costumes, foi neste território que homens e mulheres acabaram construindo diálogos de práticas sociais, muitas vezes conflituosas e com violência, como nas casas de taberna, nas regiões de produção, nas bodegas, nos espaços religiosos, nas mais diversas atividades de rua etc.

No texto da constituição que seria proposto ao Império, em 1823, apareceria o reconhecimento da Igreja Católica como religião oficial, mas previa liberdade de culto a outras, desde que em prédios específicos sem características de templo. No Código Criminal de 1831, a grande questão colocada para as outras religiões era a de respeitar a moral pública. Abria-se assim um precedente para a repressão. Quais seriam os parâmetros da moral pública? Observamos nas fontes que estes parâmetros não eram estanques, e muitas vezes os policiais agiam conforme suas avaliações próprias. Algumas vezes, os batuques eram denunciados por vizinhos, outras, a música e cantos altos os denunciavam. Mas duas questões faziam temer as autoridades: o estranhamento à feitiçaria e o medo do ajuntamento de pessoas.

No caso dos batuques, o que potencializava maiores preocupações das elites era o acoitamento de escravos fugidos nestes espaços. ${ }^{9}$ O jornal liberal Diário de Pelotas, numa terça-feira do agosto de 1878, anunciava: "Polícia Particular - Dia 7 - Foram presas, à ordem do Sr.

8 Telegrama do Presidente da Câmara Municipal ao Presidente da Província, 14 de abril de 1873, Arquivo Histórico do Rio Grande do Sul (AHRS), Fundo Autoridades Municipais. Caixa 48, Maço 108.

9 Paulo Roberto Staudt Moreira, Entre o deboche e a rapina: os cenários sociais da criminalidade popular (Porto Alegre - século XIX), Porto Alegre: Armazém Digital, 2009; Eduardo Silva, João José Reis, Negociação e conflito: a resistência negra no Brasil escravista, São Paulo: Companhia das Letras, 1989, p. 44. 
Dr. Delegado de Policia, duas pretas, feiticeiras, que faziam ajuntamento de seus adeptos". ${ }^{10} \mathrm{O}$ mesmo jornal relacionava prostituição e feitiçaria, numa tentativa de maior desqualificação da mulher presa: ${ }^{11}$

Foi ontem chamada a policia a meretriz Anna Maria, moradora à rua 3 de Fevereiro, conhecida por suas relações com a feitiçaria e por ser filiada a escola de ridículas promessas a Santo Antonio, que parece ter sofrido alguns banhos no poço.

Depois de severamente admoestada, Anna Maria retirou-se aos lares, prometendo abandonar esses hábitos.

Aconselhamos-lhe que não brinque muito com santo Antonio, porque este amigo pode estar um dia de mau humor [...] e então com certeza vira-se o feitiço contra a feiticeira. ${ }^{12}$

A devoção de Anna Maria a Santo Antonio poderia estar relacionada a algumas crenças em favores que este concederia. Santo Antônio era presença constante nas manifestações do catolicismo africano, sendo visto como poderosa entidade protetora, com capacidades curativas e promotoras da fecundidade. Era representado como santo guerreiro. ${ }^{13}$ Já o banho no poço pode ser uma forma de punição ao santo, por não ter realizado algum pedido de seus devotos, prática comum nas crenças populares oitocentistas. ${ }^{14} \mathrm{Na}$ umbanda, atualmente, Santo Antonio é relacionado com o orixá Xangô, zeloso da Justiça.

10 Jornal Diário de Pelotas, 9 de abril de 1878, Centro de Documentação e Obras Valiosas $(C D O V)$ da Biblioteca Pública Pelotense $(B P P)$, p. 3.

11 Em oposição às mulheres tidas como "honestas", que não circulavam sozinhas pelas ruas, as mulheres populares tinham uma alta circulação e eram muitas vezes vistas como prostitutas. Moreira, Entre o deboche e a rapina, p. 91.

12 Jornal Diário de Pelotas, 21 de janeiro de 1879, CDOVBPP, p.1.

13 Robert W. Slenes, "Malungu ngoma vem!: África coberta e descoberta do Brasil", Revista $U S P$, n. 12 (1992), pp. 48-67; Robert W Slenes, "Saint Anthony in the Crossroads in Kongo and Brazil: 'Creolization' and Identity Politics in the Black South Atlantic, ca. 1700-1850", in L. Sansone, E. Soumonni e B. Barry (orgs.), Africa, Brazil and the Construction of TransAtlantic Black Identities (Trenton, Asmara: Africa World Press, 2008), pp. 209-54; e Marina de Mello e Souza, Reis negros no Brasil escravista. História da festa de coroação de Rei Congo, Belo Horizonte: Editora UFMG, 2002; Mary Karasch, A vida dos escravos no Rio de Janeiro (1808-1850), São Paulo: Companhia das Letras, 2000, pp. 347-8.

14 Segundo Xavier, no Brasil, "era comum que os devotos se dirigissem diretamente aos santos de suas predileções dispensando a interferência dos padres e de seus sacramentos, pedindolhes favores. Os santos eram os mediadores ideais mais sensíveis e próximos, entre eles e a esfera divina, entre o mundo natural e o sobrenatural. Seguidamente, pessoas aflitas, diante dos problemas os mais variados que iam desde aqueles mais corriqueiros até os aparentemente mais insolúveis, voltavam-se para os santos, pedindo-lhes que interferissem em suas vidas cotidianas e trouxessem alento para suas angústias e aflições, proporcionando-lhes bem-estar. 
Tomamos aqui a expressão "feitiçaria" como um termo construído pelas elites na interpretação amedrontada da religião do outro. $\mathrm{O}$ estranhamento cultural perante o desconhecido, relacionado a um imaginário desqualificador das práticas religiosas tidas como exóticas, fez com estes indivíduos utilizassem a expressão pejorativamente. Para os "feiticeiros" e "enfeitiçados", os feitiços faziam parte de uma cosmologia religiosa específica, que trazia conforto espiritual e material e cuja devoção cimentava solidariedades. ${ }^{15}$

O escravo Antonio, que assassinou o liberto Tomás, identificavase como carneador e trabalhava e morava em uma charqueada. Seu trabalho na época do crime consistia em retirar os couros do gado, de forma impecável, com o máximo de cuidado para não cortar a peça. Após a retirada do couro, começava o corte da carne. Carneadores separavam ossos, peles e couros. Toda a cena, da matança até o esquartejamento do animal, durava poucos minutos.

Pela definição mais usual, carneador era o trabalhador de charqueada que "desmanchava a rês abatida". Pelo que deu para ver no caso do Antonio, era uma profissão importantíssima na charqueada, pois tinha que ter maestria em tirar o couro com cuidado e depois retalhar o animal. Mas temos que mencionar também que ele era cozinheiro, não se sabe se da charqueada ou do trabalho doméstico. Igualmente, como em outro caso que veremos, parece não ter sido rara a associação entre os ofícios de carneador e cozinheiro. Quiçá a destreza com a faca e o conhecimento da anatomia bovina os tornasse aptos a assumir as tarefas de cozinhar para seus parceiros de senzala e outros trabalhadores livres. Talvez essa sua inserção na esfera doméstica é que tenha potencializado o seu capital relacional, dando-lhe informações sobre as redes sociopolíticas da família senhorial, ampliando seu campo de sociabilidade.

Podemos imaginar Antonio fazendo parte deste processo produtivo, que demandava destreza e força, onde qualquer erro poderia ser

Para obter tais auxílios, eram capazes de fazer tratos variados: prometiam agrados os mais diversos, faziam-lhes confidências etc. No caso de seus pedidos não serem atendidos, no entantoo, podiam, com o mesmo ardor, puni-los, xingá-los, atirando suas imagens nos cantos". Regina Célia Lima Xavier, Religiosidade e escravidão, século XIX: mestre Tito, Porto Alegre: Editora da UFRGS, 2008, pp. 149-50.

15 Sobre o medo da religião do outro, ver: Yvonne Maggie, Medo do feitiço: relações entre magia e poder no Brasil, Rio de Janeiro: Arquivo Nacional, 1992. 
motivo para punição, para castigo, como de fato aconteceu com ele. A produção nas charqueadas foi adquirindo caráter de especialização, conforme avançaram os anos e práticas no século XIX. Especialização e racionalização comprovada por alguns autores, baseada na insistência da utilização do trabalho escravo, mesmo que com a importação de maquinário e mão-de-obra estrangeira livre. Bruno Pessi em seu trabalho, comprovou a partir de inventários dos charqueadores pelotenses, a racionalização e especialização do trabalho escravo nas charqueadas em um contexto de crise de braços, a partir das leis que restringiam a escravidão. ${ }^{16} \mathrm{O}$ autor encontrou aprendizes de carneador, por exemplo, na década de 1870. A prática de Antonio já era vista como especializada, tanto que o erro que levou aos castigos que provocaram suas fugas vinha da falta de destreza no corte do couro. ${ }^{17}$

O preço médio de um escravo homem na charqueada, entre 187074 , era de 1:122\$500 réis. No período teria havido em torno de 43 escravos por charqueada, de acordo com a pesquisa de Pessi. O autor ainda encontrou evidências de um incentivo à extensão da idade produtiva devido à falta de braços e um aumento da perspectiva de vida escrava.

Após a Guerra do Paraguai, a produção do charque em Pelotas declinou lentamente, recuperando-se na década de 1870-80. Na safra de 1880-81 chegaram a ser abatidas 250 mil reses, contra 47 mil na safra de 1868-69. ${ }^{18}$ Em 1878, chegaram a existir na cidade, de acordo

16 Bruno Stelmach Pessi, "O impacto do fim do tráfico na escravaria das charqueadas pelotenses (C. 1846 - C. 1874)" (Monografia de conclusão de curso de graduação em História, UFRGS, 2008).

17 A complexidade da unidade produtiva charqueadora se evidencia pela diversidade dos trabalhadores que comportava. Além de carneadores, ali se ocupavam salgadores, tripeiros, graxeiros, chimangos, serventes e marinheiros. A palavra chimango é que causa mais estranheza, já que na história política sulina demarca depreciativamente os membros do Partido Republicano Riograndense. Etimologicamente vem do guarani xim'xima e refere-se a uma ave característica do Brasil meridional, Uruguai, Argentina, Chile, Paraguai e Bolívia. Ave rapineira de tamanho mediano, sua predileção é pelo consumo de carniça, mas pode atacar animais feridos ou doentes, individual ou coletivamente. Os trabalhadores chimangos eram, provavelmente, encarregados de sacar dos ossos restos de carne, após o desempenho especializado dos seus parceiros carneadores: "Trata-se dos trabalhadores iniciantes e/ou em fim de carreira (que nas charqueadas poderia significar um prazo de validade bem curto, dado a bruteza do serviço) que auxiliam em tarefas gerais, recolha de peças de carne, carregamento de pilhas de charque, limpeza da pista, sempre como auxiliares menores e desqualificados, até aprenderem uma das especialidades do trabalho saladeiril". José Martinho Remedi, Condição (sub)humana. Um estudo das representações do universo saladeiril no romance Xarqueada de Pedro Wayne (Dissertação de Mestrado, Universidade Federal do Rio Grande do Sul, 1997), p. 158; Batista Bossle, Dicionário Gaúcho Brasileiro, Porto Alegre: Artes e Ofícios, 2003, p. 147.

18 Alvarino da Fontoura Marques, Episódio do ciclo do charque. Porto Alegre: EDIGAL, 1987, p. 92. 
com Beatriz Loner, cerca de 34 charqueadas. ${ }^{19}$ Importante destacar as discussões entre Vargas e Araújo, que problematizaram os números levantados pelo censo de 1872 a partir das listas de matrículas dos escravos, encontrando em 1873 o número de 7.687 trabalhadores escravos. Em 1884, o número ainda atingia expressivos 6.526 escravos, bem diferente dos 3.575 registrados no censo de $1872 .^{20}$

Carneadores parece ser um grupo que demandava gastos com fugas para os charqueadores. Em um levantamento dos anúncios de fugas de escravos, entre os anos de 1875 e 1888, Corrêa encontrou a categoria como uma das mais frequentes na descrição das ocupações dos fujões. ${ }^{21}$ Dentro dos $27,2 \%$ de anúncios que tinham a descrição da profissão dos 151 fujões envolvidos, os carneadores só perdiam para os campeiros, com $13,9 \%$.

\section{A arquitetura relacional de Antonio}

Como bem escreveu o historiador João José Reis, reincidentemente a história dos dominados vem à tona pela pena dos escrivães de polícia, dos juízes, dos advogados criminais. ${ }^{22}$ Às vezes, involuntariamente, esses especialistas nos auxiliam, e em outros momentos suas indagações clareiam trajetórias e experiências dos indivíduos que pretendem punir.

Em dois dos depoimentos dados pelo escravo homicida, foram feitas perguntas relativas a seu passado anterior a sua vida na charqueada em Pelotas. A intenção do juiz e promotor era esclarecer se ele já estivera envolvido em outro crime, mas, apesar da vereda ter sido aberta, por qualquer motivo não aprofundaram a questão.

Perguntado se havia cometido um crime em sua província de origem, o pernambucano Antonio informou que lá fora escravo de Manoel

19 Beatriz Loner, "1887: A revolta que efetivamente não houve ou de como abolicionistas se tornaram zeladores da ordem escravocrata”, História em Revista, v. 3 (1997), pp. 29-52.

20 Jonas Moreira Vargas, "Das charqueadas para os cafezais? O comércio de escravos envolvendo as charqueadas de Pelotas (RS) entre as décadas de 1850 e 1880", Anais do $5^{\circ}$ Encontro Escravidão e Liberdade no Brasil Meridional. Porto Alegre: UFRGS, 2011, p. 1-19, esp. 3; Thiago Leitão Araújo, "Novos dados sobre a escravidão na província de São Pedro", Anais do $5^{\circ}$ Encontro Escravidão e Liberdade no Brasil Meridional. Porto Alegre: UFRGS, 2011, p. 1-20.

21 Marcelo Farias Corrêa, Deu uma de vila-diogo e fitou cipó: os anúncios de fugas de escravos nos jornais pelotenses (1875-1888), Pelotas: UFPel, 2010, p. 31.

22 João José Reis, Rebelião escrava no Brasil. A história do levante dos malês de 1835, São Paulo: Companhia das Letras, 2003, p. 10. 
Camilo Pires Falcão, morador em Recife, na Rua do Hospício. Mandado para a cadeia daquela cidade, quando era Chefe de Polícia o Doutor Abílio José Tavares da Silva, ali permaneceu 8 ou 9 anos, "não sabendo o motivo porque por todo esse tempo o conservaram preso". ${ }^{23}$

Em 1889, com 75 anos de idade, Manoel Camilo Pires Falcão escreveu o próprio testamento, no qual nos informa haver nascido em 15 de julho de 1814, no Engenho Guerra, na freguesia de São Miguel de Ipojuca, na comarca do Cabo, filho legítimo do capitão Francisco Ribeiro Peres e Ana Inês da Rocha Falcão, "ambos já há muito falecidos". Ele declara ter casado apenas uma vez, com dona Carolina Cecilia da Gama Lobo, que faleceu em 24.11.1886, "não deixando descendência, e deste matrimônio só tivemos um filho João Camilo Pires Falcão que faleceu solteiro em 26.22.1880, por quem muito tenho chorado". Católico e pobre, o comendador Falcão morreu em julho daquele ano de 1889, ocupando a cela número 15 , no segundo andar do Convento de Nossa Senhora do Carmo. ${ }^{24}$

O detalhamento fornecido por Antonio sobre sua vida pregressa nos convence de que realmente sua prisão em Pernambuco ocorreu. Talvez ele não tenha contado o motivo para que não se somasse a sua culpa na morte do preto liberto Tomás. De qualquer maneira, ele informa que, mesmo preso, foi vendido a Joaquim Rasgado, por intermédio de João Gonçalves Cascão. Desvela-se aí uma interessante pista sobre o tráfico interprovincial, que abastecia o Rio Grande do Sul de cativos,

${ }^{23}$ O dr. Abilio substituiu o juiz de Direito e chefe de Polícia interino, Dr. Carlos de Cerqueira Pinto, e, conforme o ofício enviado ao delegado de Polícia suplente do $1^{\circ}$ distrito do Recife, Miguel Bernardo Vieira de Amorim, tomou posse da chefatura em 25 de novembro de 1862. Ele ficou no cargo até 1864, quando foi substituído por José Pereira da Silva Moraes. Naquele mesmo ano, por decreto de 30 de maio, assumiu como juiz de Direito de Olinda, correspondendo aos termos de Olinda e Iguarassú. O doutor Abilio, de 25 de abril a 10 de maio de 1867, governou como vice-presidente da província de Pernambuco e faleceu em 12 de dezembro de 1871, abintestado, deixando a viúva dona Maria Carolina Tavares da Silva e dois filhos: Manoel, de 12 anos, e José, de 7. Relatório como que o Comendador Dr. Domingos de Souza Leão entregou a administração da província ao $1^{\circ}$ vice-presidente Desembargador Anselmo Francisco Peretti, $1^{\circ}$ de dezembro de 1864, Arquivo Público do Estado de Pernambuco (APEJE), Recife: Tipografia do Jornal do Recife; APEJE, fundo Secretaria de Segurança Pública, maços 419, 419 A e 420; Inventário dos bens que ficaram com falecimento do Doutor Albino José Tavares da Silva, 4 de janeiro de 1872, Instituto Arqueológico Histórico e Geográfico de Pernambuco, Juízo de Órfãos, Cartório de Recife.

${ }^{24}$ Testamento do Comendador Manoel Camilo Pires Falcão, Testamenteiro: Antonio Gonçalves de Matos, 30 de julho de 1889, Instituto Arqueológico, Histórico e Geográfico de Pernambuco, Juízo da Provedoria de Recife. 
comprados mesmo em estabelecimentos prisionais. ${ }^{25}$ Joaquim Rasgado, opulento charqueador, tinha capital para importar trabalhadores cativos de outras províncias, os quais, mesmo que portadores de currículos turbulentos, ele julgava possível adestrar em seu estabelecimento. Talvez cativos como Antonio, tidos como uma aquisição de risco, fossem adquiridos por preços mais em conta nesse mercado de almas e corpos.

O tenente coronel da Guarda Nacional Joaquim Rasgado era brasileiro, filho de um homônimo, e aparece na lista de votantes de Pelotas de 1880 como charqueador, 53 anos e casado. Morava na Praça Pedro II, sabia ler e escrever. ${ }^{26}$ Foi casado com Maria Praxedes da Cunha Rasgado, nascida nessa província, filha legítima do tenente José Inácio da Cunha, um dos charqueadores mais ricos de Pelotas, e Zeferina Gonçalves da Cunha, irmã do barão de Corrientes, Felisberto Inácio da Cunha. A charqueada de Joaquim Rasgado se localizava nas margens do arroio São Gonçalo, entre os estabelecimentos de Honório Luís da Silva e dos herdeiros de Antônio José de Oliveira Castro. O tenente coronel Rasgado comprara a charqueada dos herdeiros de João Jacintho de Mendonça.

Uma irmã do senhor de Antonio também era casada com outro charqueador, mostrando como as redes socio-familiares eram estreitas nesta localidade: Constância Soares Barboza era casada com Domingos Soares Barboza, natural da cidade de Braga na freguesia da Sé, estabelecido na margem direita do arroio Pelotas com sua charqueada, movida pelo braço de mais de 50 escravos. ${ }^{27}$

25 Joaquim Gonçalves Cascão era natural do Reino de Portugal, freguesia de Santo Estevão de Gião, filho legítimo de Antônio Gonçalves Cascão e Ana Maria de Jesus. Joaquim e seu irmão, Manoel Gonçalves Ferreira, eram sócios de uma casa de consignação instalada em Rio Grande. No inventário post-morten do irmão de Joaquim, de 1865, a casa de negócios de ambos foi avaliada em mais de 7 contos de réis. Inventário, 1865, APERS, $2^{\circ}$ Cartório Cível e Crime, inventário $n^{\circ} 137$, maço 4. Agradecemos ao historiador Jovani Scherer por estas informações.

26 Atual Praça Coronel Pedro Osório no centro da cidade.

27 Denise Ognibeni, Charqueadas pelotenses no século XIX: cotidiano, estabilidade e movimento (Dissertação de Mestrado, Pontifícia Universidade Católica do Rio Grande do Sul, 2005), p. 164. Rasgado enviuvou em 12 de outubro de 1904 e, nessa ocasião, tinha os seguintes filhos: o doutor em medicina Joaquim Rasgado (casado com Maria José Dias de Castro, moradores em Pelotas), o tenente José Inácio da Cunha Rasgado (casado com Maria da Gloria Lemos Rasgado, moradores em Porto Alegre), Noemy Grounauer (casada com Alexandre Grounauer) e Clotilde Rasgado (solteira, maior). Inventário, 1912, APERS, $2^{\circ}$ Cartório do Civel, $\mathrm{n}^{\mathrm{o}}$ 500, maço 12. Inventariado: Joaquim Rasgado, inventariante: Joaquim Rasgado; Inventário, 1905, APERS, $1^{\circ}$ Cartório de Órfãos e Provedoria, ${ }^{\circ} 1526$, maço 82. Inventariado: Maria Praxedes da Cunha Rasgado, inventariante: Joaquim Rasgado. Agradecemos parte destas informações ao historiador Jonas Moreira Vargas. 
Como o tenente coronel Joaquim Rasgado faleceu em 17 de junho de 1912, em Pelotas, seu inventário evidentemente não traz informações acerca da presença de escravos em seu estabelecimento charqueador. Mas podemos, precariamente, nos valer de outras fontes para esta descrição do espaço em que viveu e trabalhou por cerca de 10 anos o crioulo pernambucano Antonio.

Poucos anos depois daquele fatídico 15 de janeiro de 1879, o movimento abolicionista e a resistência explícita dos escravos fez com que os senhores acionassem algumas estratégias tendentes a não perder o controle sobre seus trabalhadores cativos. Em 1883, mas principalmente em 1884, os senhores de escravos do Rio Grande do Sul, percebendo a ameaça de descontrole dos trabalhadores escravizados que pairava sobre as suas casas e unidades produtivas, trataram de despretensiosamente concederem maciçamente cartas de alforria. Claro que essas concessões de alforria não foram gratuitas, porque a escravidão ainda era a base da produção e do sistema de controle dos trabalhadores sulinos. O coronel Joaquim Rasgado, sentindo a retomada do movimento abolicionista, tratou de negociar com os cativos de seu plantel a continuidade disfarçada dos laços do cativeiro.

Em 23 de setembro de 1884, o tenente coronel Salgado redigiu quatro cartas de alforria, que foram registradas em cartório no dia 2 de outubro do mesmo ano. O texto desses documentos de liberdade é praticamente o mesmo, sendo concedidas:

[...] debaixo das condições seguintes: ficam os libertos sujeitos a continuar a prestar seus serviços a mim, ou quem minhas vezes fizer por espaço de $[\ldots]$ anos a contar da presente data, e só por acordo recíproco desaparecerá o meu poderio antes do prazo acima estipulado, ficando entendido que o serviço de cada um é arbitrado na razão de [...] mensais, sujeitos os libertos à disposição do art. $4^{\circ}, \S 5^{\circ}$ da Lei de 28-09-71; e 63 do respectivo Regulamento 5135 de 13-11-72 e mais Leis em vigor. Outrossim, comprometo-me a dar-lhes alimentação e roupa precisa.

A primeira carta alforriou 13 escravos, com a condição de prestarem 6 anos de trabalho, sendo os serviços de cada um avaliado em 25 mil réis mensais; a segunda libertou 17 escravos, com a obrigação de 5 anos de trabalho, avaliados os serviços em 20 mensais; a terceira outorgou a liberdade disfarçada a 9 cativos, obrigando-os a continuar a trabalhar por 7 anos e avaliando os serviços em 30\$ mensais; o derra- 
deiro documento de alforria libertou 4 cativos, estipulando 3 anos de trabalho, os quais seriam remidos com a indenização de $12 \$$ mensais. Partindo destas alforrias concedidas em 1884, temos uma escravaria de 43 cativos na charqueada do tenente coronel Joaquim Rasgado. ${ }^{28}$

Como podemos perceber no que foi dito anteriormente, 43 escravos era um plantel médio para as charqueadas pelotenses. Mas, dificilmente, a comunidade da senzala de Joaquim Rasgado se limitava aos cativos listados acima. Lembremos que provavelmente havia ingênuos (filhos do ventre livre, da Lei de 28 de setembro de 1871) que ainda permaneciam ao lado de suas mães e prestavam serviços na charqueada. Além disso, já verificamos em pesquisas anteriores que trabalhadores livres também prestavam serviços nesse tipo de estabelecimento. ${ }^{29}$ Igualmente, outros indivíduos imersos ainda em laços de trabalho compulsórios ali viviam, como o pardo Crescêncio, de 20 anos, apto para todo o serviço, ex-escravo de João Frutuoso Lucas. Em 15 de outubro daquele mesmo ano de 1884, o senhor Lucas passou uma carta de alforria para Crescêncio, com a condição de ele prestar mais cinco anos de serviço a Joaquim Rasgado "ficando entendido que o serviço é arbitrado na razão de $20 \$$ mensais" e que o charqueador ficava "obrigado a prestar ao liberto alimentação, tratamento médico e roupa precisa". O texto da carta não é claro a respeito, mas é provável que Rasgado tenha adiantado a quantia necessária para a liberdade de Crescêncio, ou quem sabe o senhor Lucas tinha alguma dívida com esse charqueador e assim a saldou. ${ }^{30}$

Ou seja, na charqueada de Joaquim Rasgado circulavam traba-

${ }^{28}$ APERS - Livros Notariais de Registros Ordinários de Pelotas, Livro 15, folha 4r, 4v, 5r,6r RIO GRANDE DO SUL. Secretaria de Administração e Recursos Humanos. Departamento de Arquivo Público. Catálogos seletivos sobre a escravidão no Rio Grande do Sul. Porto Alegre: CORAG, 2010.

29 Paulo Roberto Staudt Moreira, "Podem minha cabeça e orelhas levar, mas meu corpo não: os processos criminais como fontes para a investigação das culturas negras meridionais", in Rio Grande do Sul. Secretaria de Administração e Recursos Humanos, Departamento de Arquivo Público, Catálogos seletivos sobre a escravidão no Rio Grande do Sul (Porto Alegre: CORAG, 2010).

30 Em 25 de outubro de 1869, anos antes do que estamos tratando, a sogra de Joaquim Rasgado, Zeferina Gonçalves da Cunha, passou uma carta de alforria para seu escravo africano de nação mina, Roberto, de 40 anos, mediante o pagamento, pelo escravo, de 2 contos e réis. $\mathrm{O}$ teor desse documento nos leva a cogitar que Rasgado tenha adiantado a quantia para que Roberto se distanciasse do cativeiro, pois trazia como condição "ficar servindo pelo espaço de 2 anos a contar desta data, na charqueada que tenho arrendada a meu genro Joaquim Rasgado, percebendo de aluguel 32\$ mensais". Carta de Alforria, 26 de outubro de1869, APERS, livro 8, p. 14v, livro 10, p. 21r. 
lhadores escravos, contratados, libertos, livres, ingênuos e sabe-se lá quantas outras formas de relações de trabalho. ${ }^{31}$ Menos de um ano antes da Lei Áurea, em 19 de maio de 1887, um drama da escravidão ocorrido em plena charqueada do tenente coronel Rasgado evidencia a presença de escravos de terceiros ali alugados. Deixemos que os cronistas do jornal Correio Mercantil nos relatem o que transcorreu naquela madrugada trágica:

Assassinato - Ás 3 1⁄2 da madrugada de quinta-feira, o preto Firmino, escravo do Sr. Antonio Jacomo Villaça, alugado na charqueada do Sr. tenente-coronel Joaquim Rasgado, assassinou a traição a Antonio Martins das Neves, capataz daquele estabelecimento, nas seguintes circunstancias: $\mathrm{O}$ mencionado preto não desempenhara um serviço que lhe tinham indicado e, sendo por tal repreendido pelo capataz, insultouo, recebendo em troca algumas chicotadas. Parecendo humilhar-se com a correção, foi mandado para o serviço, consentindo ainda do capataz que o preto afiasse uma faca de carnear, como ele lhe pedira. Momentos depois, quando cada um achava-se preocupado com a sua tarefa, o preto, vendo Neves distraído, abraçou-o pelas costas, jungiu-o entre os antebraços e com um rápido golpe de faca, produziu-lhe no ventre um horroroso ferimento em forma de semicircular, pelo qual irromperam logo os intestinos. Ato contínuo, fugiu em direção ao trapiche da charqueada, sobre o rio S. Gonçalo, e ai parou, despindo-se, tendo a faca tinta de sangue atravessada nos dentes. Acudiu logo o pessoal da charqueada em perseguição do assassino, mas este, ameaçando a todos com a faca, acabou de despir-se e atirou-se ao rio, fugindo em direção á margem oposta, não se sabendo mais o caminho que tomou. Ao inditoso Neves foram imediatamente prestados os cuidados de que carecia, inutilmente, porque ás 2 horas da tarde de quinta-feira faleceu no meio de cruciantes dores. Era o Sr. Antonio Martins Neves natural de Portugal, casado e contava apenas com 47 anos de idade. Dotado de excelentes qualidades, rigoroso cumpridor de seus deveres, era sempre procurado para administrar estabelecimentos da ordem do Sr. tenente-coronel Rasgado. Foi capataz da charqueada do Sr. Barão de Santa Tecla, e, deixando-a, fez um passeio a sua pátria, donde regressara havia pouco tempo.

${ }^{31}$ No ano seguinte, 1885, encontramos o tenente coronel Joaquim Rasgado passando outras cartas de alforria, não para escravos próprios, mas para cativos beneficiados pela Junta Classificadora de Escravos municipal, atuando como Juiz de Órfãos suplente. APERS - Livros Notariais de Registros Ordinários de Pelotas, Livro 10, folha 33v, 34r., 34v. 
A noticia de seu passamento foi recebida com geral consternação, e o sepultamento de seu cadáver, realizado ontem, muito concorrido. Mais um, para acrescentar ao catalogo dos dramas da escravidão. ${ }^{32}$

Os pesquisadores que usam os processos criminais como base primária de suas investigações sabem que os crimes relatados nestes documentos valem menos pelo ato violento que registram, do que pelos detalhes que nos trazem das experiências afetivas, de trabalho e da vida em geral dos personagens envolvidos. Pela descrição acima, percebemos que o preto Firmino conseguiu o que o crioulo Antonio desejava: vingar-se do capataz por humilhações recebidas. O palco do esfaqueamento foi a charqueada, que às 3 e meia da madrugada, ainda estava em ritmo acelerado de produção. Firmino provavelmente era carneador como Antonio, mas o português Antonio Martins Neves não tinha como adivinhar que ele afiaria a faca de carnear, não para desempenhar seu ofício, mas para gravar-lhe no ventre um mortal semicírculo.

Neves, conforme os cronistas, voltara a pouco de Portugal e talvez não estivesse ainda bem acostumado com a dinâmica das relações da charqueada de Rasgado. A admoestação e as chicotadas que atingiram o preto Firmino não foram consideradas justas. ${ }^{33}$ Quiçá a humilhação sentida pelo preto Firmino fosse um indicativo da valoração desses trabalhadores na hierarquia do trabalho das unidades charqueadoras, cuja honra profissional não podia ser ultrajada sem cuidado.

Os carneadores Firmino e Antonio exerceram a maestria de seus ofícios nas vinganças que promoveram. Firmino na marca semicircular que gravou no ventre do capataz lusitano e que fez com que seus intestinos ficassem expostos, Antonio nas três facadas incisivas que deu no liberto Tomás e na rapidez assombrosa com que embainhou a arma do crime, provavelmente sua faca de carnear. Não pode passar despercebido o simbolismo desses atos sanguinolentos: prostrar os inimigos com o instrumento de trabalho com que rotineiramente abatiam animais vacuns equivalia a derrotá-los duplamente: pela morte que causavam e pelo aviltamento de seus cadáveres.

Podemos ponderar que boa parte dos escravos alforriados em 1884 conviveu com o carneador e cozinheiro Antonio e com ele entreteve

32 Correio Mercantil, 21de maio de 1887, CDOVBPP, p. 1, coluna 7.

33 Sílvia Lara, Campos da violência, Rio de Janeiro: Paz e Terra, 1988. 
relações diversas, seja afetiva, étnica, de trabalho. Mas não podemos esgotar as relações de Antonio nessas redes de sociabilidade primárias. Mesmo que a lida diária das charqueadas fosse de muito trabalho e controle, é absolutamente improvável que os cativos não tecessem tramas de relações dentro e fora de suas comunidades de senzala. ${ }^{34}$ Aliás, o crime do preto feiticeiro Tomás Soares evidencia isso, com o carneador Antonio participando do mercado da crença, comprando mandinga de proteção contra senhores e capatazes.

No ano anterior ao das concessões das 43 alforrias pelo tenente coronel Joaquim Salgado, uma simples notícia de jornal nos dá pistas sobre alguns investimentos dos seus cativos em formas de economia autônoma. O jornal A Discussão, de 8 de fevereiro de 1883, informava: "Prisão - Foi hoje, preso, á ordem do Sr. subdelegado do $2^{\circ}$ distrito, o preto João, escravo do tenente coronel Joaquim Rasgado. João tinha na Várzea um quarto que servia de esconderijo para grande quantidade de roubos ali encontrados, como sejam: louça, charque, roupa e outros objetos". ${ }^{35}$ É interessante ver nessa Pelotas charqueadora um mesmo tipo de experiência já visualizada em várias outras cidades escravistas: os cativos procurarem viver sobre si e esses recantos se tornarem pontos de convergência de resistências diversas, desvio de produtos de seus senhores, acúmulo de pecúlios, estabelecimento de redes de solidariedade diversas, local de amasiamento.

A Várzea não era qualquer lugar, mas um ponto carregado de simbolismo religioso e de investimentos em parentescos étnicos. Outra notícia dos jornais locais evidencia isso:

Prisão de Feiticeiros - A policia particular efetuou anteontem, ás 10 horas da noite, na várzea, a prisão de uma tribo de feiticeiros, ou antes, de larápios industriosos; porque os feiticeiros desapareceram na mesma ocasião em que se ocultaram para sempre os astrólogos.

Agora só há feiticeiras, e estas a policia só cumpre-lhe tratá-las gentilmente.

${ }^{34}$ Em outro trabalho já demonstramos o quão complexas eram as relações entre escravos e libertos na região da cidade de Pelotas. Um exemplo interessante era a rede de informações construída entre escravos das charqueadas e das chácaras nas Serra dos Tapes que objetivavam avisar sobre as partidas organizadas contra quilombolas. Caiuá Cardoso Al-Alam, A negra forca da princesa: polícia, pena de morte e correção em Pelotas (1830-1857), Pelotas: Edição do Autor/ Sebo Icária, 2008.

35 A Discussão, 8 de fevereiro de 1883, CDOVBPP, p. 3,coluna 3. 
O comandante da policia particular, que pensa do mesmo modo, e sabe distinguir as cousas, conhece bem a diferença que existe entre feiticeiro e feiticeiras.

Por isso mesmo, anteontem, ás 10 horas, penetrou na casa de um feiticeiro e surpreendeu-o no momento em que, precedido de sua corte, trajava vestimenta imperial, semelhante a um imperador de comedia.

Pois assim mesmo trajado, o Sr. Comandante da policia particular o fez seguir para o xadrez.

E não houve apelação nem agravo, imperador e Corte lá foram a caminho da prisão.

Bravo! A policia virou a republicana. Guerra de morte aos imperadores... feiticeiros.

- Dizem-nos que este imperador já foi preso no Rio Grande, pelo subdelegado de policia, Sr. Tigre Junior.

É um desgraçado o tal imperador. ${ }^{36}$

A prisão foi feita na Várzea, tradicional território negro, localizado perto do porto da cidade, conhecido até os dias de hoje pela concentração de terreiros de umbanda e batuque. ${ }^{37} \mathrm{Na}$ notícia, vemos a exaltação de uma suposta diferença entre as "feiticeiras" e os "feiticeiros". Talvez seja uma referência às diferenças entre aquelas feiticeiras idealizadas nos mitos europeus em contraponto aos crentes de religiões de matriz africana. A liderança do espaço foi descrita como sendo um "imperador", pois trajava uma vestimenta imperial. Fica evidente que o "imperador" era uma espécie de pai de santo, trajado com as vestimentas de culto. O jornal, num tom mesclado de ironia e ignorância, desqualifica o indivíduo e o culto, chamando-o de "imperador de comédia", e comemora a prisão deste ainda com suas vestimentas de ritual. O comentário elogioso final ao subdelegado de Rio Grande, na verdade nos dá uma pista significativa do trânsito ou circularidade desses especialistas no oculto entre cidades com forte concentração negra em geral e africana em particular.

Infelizmente, os periodistas esgotaram sua verve no deboche e não nos forneceram dados mais reveladores, como o nome e procedência do imperador e de sua corte, para que pudéssemos examinar com mais minúcia esse importante traço de cimento étnico local. Reiterada-

${ }^{36}$ Diário de Pelotas, 22 de março de 1885, CDOVBPP, p. 2.

37 Marco Antonio Lírio de Mello, Reviras, batuques e carnavais: a cultura de resistência dos escravos em Pelotas, Pelotas: Universitária UFPel, 1994, p. 28. 
mente, o etnocentrismo se esteia apenas na superficialidade preconceituosa, encobrindo com isso a legitimidade e complexidade das manifestações religiosas alheias. Como escreveram Sidney Mintz e Richard Price, "superstição é a religião do outro". ${ }^{38}$

Podemos imaginar que o crioulo Antonio transitasse nestes locais de culto e, como se evidencia no processo crime de 1879, consumia artefatos místicos, compartilhando crenças com seus parceiros africanos. Mas, suas afinidades não eram apenas étnicas e sociais, pois seu circuito de apadrinhamento mostra agilidade e competência na conformação de redes de proteção, mais amplas do que o seu imediato círculo de cativos e libertos. Em seus depoimentos, Antonio explica que, temendo ser castigado por falhas cometidas, em dois momentos procurou se apadrinhar para fugir a punição prometida pelo administrador da charqueada, Serafim Pelado.

$\mathrm{O}$ apadrinhamento era um traço cultural presente no escravismo brasileiro desde seus primórdios e visava resolver conflitos que poderiam culminar em violentos desfechos. Não raro, escravos fugidos se apadrinhavam com proprietários vizinhos de seus senhores, negociando a volta para suas senzalas de origem. Em outros casos, cativos revoltados por castigos injustos recebidos, procuravam padrinhos que os possibilitassem trocar de senhores através da venda. Mas, claro que o apadrinhamento exigia sensibilidade e conhecimento, pois nem todos podiam exercer esse papel. Cabia ao cativo ler e entender a rede sócio-familiar e política de seus senhores, identificando aqueles que podiam ser seus aliados, mesmo que ocasionais. Eram aptos a serem acionados indivíduos de igual ou superior poder aos senhores, portadores de capacidade de interlocução e barganha entre as partes. Claro que isso quer dizer que os administradores e capatazes deveriam saber com quem estavam tratando, pois isso afetava o controle e a administração diária dos cativos. Não era, portanto, um ardil a ser usado repetidamente, mas uma estratégia pontualmente acionada e que envolvia sérios riscos. Isso nos leva a considerar que também os escravos tinham o seu capital relacional, acumulado graças a seu papel na hierarquia da senzala e as conexões que construíam com o mundo dos livres.

38 Sidney Mintz e Richard Price, apud João José Reis, "Magia jeje na Bahia: a invasão do calundu do Passo de Cachoeira, 1785", Revista Brasileira de História, v. 8, n. 16 (1988), pp. 57-81. 
Receando ser castigado pelo dano que causara a um couro que retirara de um animal, Antonio saiu da charqueada e foi apadrinhar-se, inicialmente, com Joaquim Assumpção, dr. Gama Lobo e Leonardo Honório da Silva. Os aproximadamente quarenta anos de vida de Antonio o tornaram sabedor das manhas da sociedade escravista. Morando há dez anos em Pelotas ele já sabia localizar os indivíduos social, política e simbolicamente. Não eram quaisquer naturais pelotenses os procurados por aquele atemorizado escravo.

Joaquim José de Assumpção, na lista de votantes do $1^{\circ}$ distrito de Pelotas de 1865 , tinha 35 anos, era casado, charqueador e morava no $6^{\circ}$ quarteirão. Ele faleceu em 12 de abril de 1898, já viúvo e deixou dois filhos vivos: um seu homônimo, de 47 anos, casado com dona Maria Francisca Mendonça de Assumpção, e Ernestina de Assumpção Osório, de 41 anos, viúva do doutor Fernando Luiz Osório. Morava em um sobrado na rua Gonçalves Chaves e sua charqueada (já desativada quando do inventário de 1898) estava instalada no distrito de Santo Antonio da Boa Vista, margem esquerda do arroio Pelotas. Naquele ano de 1879, além de charqueador, Joaquim José de Assumpção era juiz municipal, sendo ele inclusive quem decretou a prisão preventiva do réu Antonio. ${ }^{39}$

Leonardo Honório da Silva era filho de Honória Julieta da Silva e neto natural de Honório Luís da Silva. Não sabemos no que se ocupava Leonardo, mas seu avô era charqueador e seu estabelecimento de charqueada se localizava no Passo dos Negros, à margem do São Gonçalo, dividindo-se pelo leste com a charqueada do tenente coronel Joaquim Rasgado. ${ }^{40}$

Já o nome completo do dr. Gama Lobo era Belchior da Gama Lobo. Não temos muitos dados sobre ele, pois consta ter-se mudado da Província sulina, primeiro para a Bahia e depois para o Rio de Janeiro.

39 Inventário, 1898, APERS, $2^{\circ}$ Cartório do Civel, $n^{\circ}$ 228, maço 6. Inventariado: Joaquim José de Assumpção (Barão Jaráo), inventariante: Joaquim Augusto Assumpção; Lista Geral dos Cidadãos Qualificados Votantes no $1^{\circ}$ Distrito de Pelotas, 3 de fevereiro de 1865, AHRS, Fundo Eleições, maço 2.

40 Ele faleceu na estação Azevedo Sodré em 27 de abril de 1904, deixando 3 filhos vivos: Carlos Natusch da Silva (solteiro, 25 anos), Celestina da Silva Bianchi (21 anos, casada com Luiz Bianchi), Emilia Natusch da Silva (19, solteira). Inventário, 1904, APERS, $2^{\circ}$ Cartório de Órfãos e Ausentes de Pelotas, $n^{\circ}$ 1160, maço 4. Inventariado: Leonardo Honório da Silva, Inventariante: Emilia Natusch da Silva; Inventário, 1880, APERS, $2^{\circ}$ Cartório de Órfãos e Ausentes de Pelotas, $\mathrm{n}^{\circ}$ 111, maço 6. Inventariado: Honório Luiz da Silva, Inventariante: Doutor Pio Angelo da Silva (testamenteiro e irmão - morava em Rio Grande). 
Aliás, pode ser encontrado (ou um seu homônimo) sendo nomeado, por portaria de 17.10.1890, como delegado de Higiene do Distrito Federal e, em 27 de outubro de 1898, comissário de Higiene e Saúde Pública. Em 1906 foi qualificado jurado no Distrito Federal, pelo juiz de Direito da $1^{\text {a }}$ Vara Criminal. ${ }^{41} \mathrm{O}$ dr. Gama Lobo era, em 1874, irmão da Santa Casa de Misericórdia de Pelotas, casado, formado em medicina, nascido no Brasil, mas de família lusitana e dez anos antes estava clinicando na cidade de Alegrete. ${ }^{42}$

Os leitores atentos, e que ainda não se afogaram em nomes, devem ter percebido que no testamento do senhor pernambucano de Antonio, Manoel Camilo Pires Falcão, constava que ele era viúvo de dona Carolina Cecilia da Gama Lobo, falecida em 24.11.1886. Mesmo que seja possível tratar-se de uma coincidência, o mais provável é que Antonio tenha, na sua ânsia de apadrinhamento, achado um parente de sua ex-senhora, buscando sorte e fortuna no Brasil Meridional. Quiçá a vinda de Antonio de Recife, via a casa de consignação dos irmãos Cascão, em Rio Grande, tenha sido intermediada pela presença do doutor Gama Lobo em Pelotas.

O apadrinhamento deu certo e o administrador Serafim Pelado não efetivou o castigo esperado, mas para não parecer desprestigiado em seu papel de administrador, bateu no ombro do pernambucano Antonio e sussurrou "não faz mal, daqui a dois ou três dias estás pegado". Se para nós a palavra final não fica clara, Antonio compreendeu-a claramente como uma nada velada ameaça. Talvez Serafim tenha feito uma referência a péga, braga (peia) de ferro com que se prendiam os pés dos escravos fugitivos. ${ }^{43}$

Mas Antonio não estava realmente com sorte. Se, em 13 de janeiro, ele estragou o primeiro couro, logo no dia seguinte ele teve outro deslize e desta vez estragou uma garra: "ponta do couro, onde se furam para estaqueá-lo". ${ }^{44}$ Talvez a reincidência de Antonio no erro estivesse

${ }^{41}$ Ver o Diário Oficial: <http://www.jusbrasil.com.br/diarios/1676798/dou-secao-1-27-10-1898pg-2/pdfView - http://www.jusbrasil.com.br/diarios/1685611/dou-secao-1-18-10-1890-pg-10/ pdfView - http://www.jusbrasil.com.br/diarios/1608467/dou-secao-1-01-02-1906-pg-11/ pdfView> páginas acessadas em 26 de janeiro de 2012.

42 Agradecemos os dados da Santa Casa de Misericórdia de Pelotas à historiadora Claudia Tomaschewski.

43 Antonio de Moraes Silva, Diccionario da Língua Portuguesa, Tomo 2, Lisboa: Tipografia Lacerdina, 1813[1789], p. 419.

44 Batista Bossle, Dicionário Gaúcho Brasileiro, p. 263. 
relacionada com o ciclo produtivo do charque, sendo que a época da matança e os procedimentos de preparação do charque que se seguiam ao abate, iniciavam em novembro e se estendiam até maio, ou seja, concentravam suas atividades entre a primavera e o outono, embora pudesse se prolongar para os meses de inverno. Os deslizes de Antonio podiam estar relacionados não a sua incompetência profissional, mas ao cansaço provocado pelo ritmo alucinante de trabalho. ${ }^{45}$

Receando "ser pegado" pelo administrador, novamente Antonio saiu em busca de proteção, mas como não podia abusar dos primeiros padrinhos, sacou outros dois que também o podiam resguardar: "fugiu da charqueada e veio apadrinhar-se com o Dr. Barcelos e o Dr. Abreu", ambos médicos formados na escola de medicina do Rio de Janeiro.

Na lista eleitoral de Pelotas de 1865, encontramos o médico Antônio Francisco dos Santos Abreu, então com 32 anos, casado com Crescência Montano de Abreu, morador no $1^{\circ}$ Distrito ( $9^{\circ}$ Quarteirão). ${ }^{46}$ Abreu era filho primogênito de um homônimo e Perpétua da Silva Santos Abreu. ${ }^{47}$ Seu pai faleceu em Rio Grande em 18.04.1884, deixando vários bens, entre eles a Fazenda São Lourenço, 3.120 reses de cria e 29 escravos.

$\mathrm{O}$ dr. Barcellos provavelmente era Miguel Rodrigues de Barcelos (barão de Itapitocay), nascido em Pelotas em 1827, falecido na mesma cidade em 13 de fevereiro de 1896.

Diplomou-se em medicina no RJ [em 1848] e exerceu a profissão em sua terra natal. Foi deputado provincial na legislatura de 1856/1867, ligado ao Partido Conservador. Na condição de Vice-presidente da província, assumiu a presidência desde 20.09 .1885 até 28.10 do mesmo ano. ${ }^{48}$

O dr. Barcelos era filho de Silvana Eulália de Azevedo Barcelos e do guarda roupa comendador Boaventura Rodrigues Barcelos. Sua mãe,

45 Gabriel Berute, "Rio Grande de São Pedro do Sul: uma análise do tráfico doméstico de escravos (1788-1822)" (Dissertação de Mestrado, Universidade Federal do Rio Grande do Sul, 2006), pp. 49-50; e Berenice Corsetti, "Estudo da charqueada escravista gaúcha no século XIX” (Dissertação de Mestrado, Universidade Federal Fluminense, 1983).

${ }^{46}$ Lista Geral dos Cidadãos Qualificados Votantes no $1^{\circ}$ Distrito de Pelotas, 3 de fevereiro de 1865, AHRS - Fundo Eleições, maço 2.

47 Inventário, 1884, APERS, $2^{\circ}$ Cartório do Civel, n²10, maço 6. Inventariado: Antonio Francisco dos Santos Abreu. Inventariante: Perpétua da Silva Santos Abreu (viúva).

48 Sérgio da Costa Franco, Dicionário Político do RGS - 1821/1937. Porto Alegre: Suliani Letra \& Vida, 2010, p. 37. 
nascida nesta província e falecida em 13 de novembro de 1878, era filha legítima do sargento mor Francisco de Azevedo Souza e Josefa Maria da Cunha Azevedo. ${ }^{49}$ Miguel casou com Eulália Bárbara de Azevedo, filha de Heleodoro de Azevedo e Souza e Eulália Bárbara da Silva, em 7 de janeiro de 1852, em Pelotas.

O sogro do doutor Barcelos, Heleodoro de Azevedo e Souza, nasceu em Rio Grande, em 12 de julho de 1804 e faleceu em Pelotas em 12 de julho de 1887, filho legítimo do major Francisco de Azevedo e Souza e Josefa Maria da Cunha. Ele casou, em 20 de outubro de 1829, com Eulália Bárbara da Silva e teve 3 filhos: Eulália Bárbara de Azevedo (nascida em 18 de setembro de 1830), Clara Maria de Azevedo (nascida em 2 de maio de 1832 e casada com Alexandre Jacinto de Mendonça) e Heleodoro de Azevedo e Souza Filho (nascido em 27 de maio de 1833 e casado com Maria da Glória Jacinto de Mendonça).

Heleodoro era grande charqueador em Pelotas e em seu testamento redigido em 22 de outubro de 1885, "de saúde e em perfeito juízo", deixou explícitas as relações íntimas que ainda ele e sua família mantinham com o genro:

Declaro que devo a meu genro o Doutor Miguel Rodrigues Barcelos muitos e grandes serviços pela dedicação, empenho e boa vontade com que sempre me tem tratado em minhas enfermidades e nos de minha família, sem remuneração alguma, pela grande estima e amizade que sempre me há distinguido. Peço aos meus que sempre o amem, estimem e respeitem, continuando a cultivar com ele as melhores relações de amizade. Tomai como uma homenagem a minha memória. ${ }^{50}$

Ambos os médicos procurados pelo crioulo Antonio possuíam sólidas raízes nas redes socio-familiares das elites sulinas, salientandose o dr. Barcelos, que era casado com a filha de um dos grandes charqueadores de Pelotas. Mas a sorte de Antonio tinha mudado e nenhum deles se prontificou a ajudá-lo. Como dissemos acima, é importante que o cativo carente de apadrinhamento saiba localizar seu senhor nas ali-

49 Inventário, 1879, APERS, Cartório de Órfãos e Provedoria, no 916, maço 53. Inventariado: Silvana Eulália de Azevedo Barcelos, inventariante: Miguel Rodrigues Barcelos (barão de Itapitocay).

50 Inventário, 1896, APERS, $1^{\circ}$ Cartório de Órfãos e Provedoria de Pelotas, $\mathrm{n}^{\circ}$ 1353, maço 73. Inventariado: Heleodoro de Azevedo e Souza e sua mulher Eulália Barboza da Silva Azevedo, Inventariante: Heleodoro de Azevedo e Souza Filho. 
anças políticas locais. Mas é claro que essas redes não são imutáveis, e compõem tramas circunstanciais, não no sentido de inúteis, mas de balizadas pelas circunstâncias dos momentos em que eram acionadas.

Antonio não havia colocado como variável nos seus cálculos as tropelias ocorridas nas eleições do ano anterior, o que talvez justifique que os dois doutores dissessem que não "se davam com o seu senhor". Nas eleições de 1878, liberais e conservadores se digladiaram pelas ruas do centro de Pelotas, com mortos e feridos de ambos os lados.

Na manhã do dia seis de agosto de 1878, na segunda reunião da Mesa Paroquial, na igreja matriz de Pelotas, ocorreu o conflito, após ser questionada a identidade de um eleitor do partido conservador. Logo se seguiu o uso de "cacetes, facas e revólveres". O conflito se estendeu para a rua, sendo morto um policial e ficando feridas muitas pessoas, dentre elas nomes como os de Luiz Rodrigues Vizeu, Leonardo Honorio da Silva (um dos que Antonio procurou para o apadrinhamento), dr. Saturnino Epaminondas de Arruda e o comandante da Guarda alferes Cordeiro. Na fuga, os conservadores procuraram proteção na casa do dr. Miguel Barcellos, liderança do partido local, justificando esse "acoutamento" por suas qualidades de médico, para o socorro dos feridos. Os liberais o acusaram de manter um foco de resistência armada em sua casa. Barcellos acabaria preso, sob custódia da Guarda Nacional, no prédio da Câmara Municipal, acusado de ter sido o homem que instigara e autorizara os tiros e a confusão. Foi solto após a sentença que o despronunciou no sumário crime instaurado pelo chefe de Polícia, que viria pessoalmente a Pelotas apurar o conflito. ${ }^{51}$

Como explica o parágrafo acima, médicos condecorados e integrantes da fina flor da sociedade local não hesitavam em correr às ruas (com seus capangas e aliados) e enfrentar seus adversários, numa acalorada disputa de eleições paroquiais. Essa rivalidade política entre as elites acabou influenciando a vida do crioulo Antonio e do africano Tomás, indicando a interdependência existente entre indivíduos tão díspares em termos sociais e étnicos. $\mathrm{O}$ que poderia ter se encerrado num ágil e corriqueiro apadrinhamento, terminou numa atroz cena de sangue. $\mathrm{O}$ administrador Serafim Pelado foi mais esperto e cuidadoso do que Antonio Martins Neves: ao contrário de Firmino, Antonio não

${ }^{51}$ Ofícios da Câmara Municipal de Pelotas, 1878, CDOVBPP, Maço 03 e 04 
conseguiu vingar-se do seu algoz mais próximo e isso ocasionou que a desgraça cercasse e abatesse ao feiticeiro Tomás.

\section{Evidências do oculto}

Certamente não foi frequentando a Várzea de Pelotas que o carneador e cozinheiro Antonio descobriu seu lado místico e passou a venerar os orixás. Já em Recife, com sua avultada população negra, ele deve ter sentido o apelo dos cultos religiosos afro-brasileiros. ${ }^{52}$

Voltando ao primeiro depoimento de Antonio, ele nos diz que fracassando sua tentativa de conseguir um segundo apadrinhamento (com os doutores Abreu e Barcelos), sentiu-se sem proteção e daí lembrou-se do que havia combinado com o feiticeiro Tomás. Precisamos reconhecer que esse crioulo pernambucano, na esteira da maioria de seus parceiros, se abrigava na comunidade etnosocial que o cercava e da qual fazia parte, mas estrategicamente se colocava sob a sombra de padrinhos poderosos, fossem estes charqueadores, médicos ou orixás. Em um de seus depoimentos, Antonio declara que matou o preto Tomás porque dele tinha comprado um:

[...] feitiço por 3 mil réis para trazer ao pescoço, afim de não ser castigado na charqueada pelo administrador, que quando comprou o feitiço, foi debaixo das seguintes condições: se produzisse o efeito desejado dar-lhe o acusado mais 3 mil réis, mas notando que continuava a ser castigado apesar do feitiço, resolveu ir cobrar o dinheiro que tinha dado pelo feitiço ou matar a Tomás para que ele não continuasse a enganar os outros.

Acreditar no feitiço (e no poder do feiticeiro) era crer em uma força possível de se opor (ou contrapor) aos senhores e seus agentes (administradores e capatazes). Envolver-se nesse mercado da crença adquirindo artigos de significado místico era também um investimento numa identidade coletiva, social e étnica, formada entre outras coisas por cumplicidades (não só as ligadas ao cativeiro) e pelo compartilhamento de saberes mágico-religiosos, curativos. ${ }^{53}$

52 Marcus J. M. de Carvalho, Liberdade: rotinas e rupturas do escravismo no Recife, 18221850, Recife: Editora Universitária da UFPE, 1998.

53 João José Reis, Flávio dos Santos Gomes, Marcus J. M. de Carvalho, O alufá Rufino: tráfico, escravidão e liberdade no Atlântico, São Paulo: Companhia das Letras, 2010, p. 305. 
O que Antonio nos descreve e que ele trazia ao pescoço, provavelmente pode ser pensado como uma mandinga ou bolsa de mandinga:

Normalmente, a bolsa era feita de pano ou cabedal e era usada à volta do pescoço ou noutras partes do corpo, segura por um cordel ou fio. Dentro da bolsa podiam encontrar-se várias substâncias, incluindo pedaços de papel dobrados com orações cristãs lá escritas, pedras, paus, raízes, ossos, cabelos, pelos de animal, penas, pós, pequenos objetos abençoados, entre outros. As várias combinações de substâncias eram receitas pensadas para ajudar as pessoas nos seus assuntos do dia-a-dia. Cada bolsa tinha as suas qualidades. Algumas protegiam a pessoa dos espancamentos do senhor. Outras asseguravam a vitória em jogos. Outras tinham o poder de ajudar os escravos a escapar à servidão. No entanto, a bolsa mais comum era a que protegia os escravos nas lutas. Estas bolsas não só protegiam o escravo de murros, como também o tornavam imune a facas, espadas e mesmo armas de fogo. ${ }^{54}$

O termo mandinga se origina do povo mandinga ou malinkês, habitante do arco do rio Niger. Mesmo que invólucros com componentes diversos já circulassem na Europa, na Idade Média, a chegada maciça de escravos da "Guiné" e da "Mina" ao mundo português, estendeu este hábito de consumo místico no século XVIII: "o uso da expressão 'bolsas de mandinga' torna claro que se procurava distinguir as bolsas africanas daquelas que eram mais familiares aos portugueses". ${ }^{55}$

O que continha o invólucro, ou bolsa, que Antonio carregava ao pescoço? Ele ainda o portava quando respondia por seu crime em juízo? Teria mostrado para as autoridades ou resguardara a materialidade de sua crença dos olhares descrentes daqueles que deliberavam sobre o seu futuro? Seriam trechos do alcorão, orações cristãs, objetos diversos?

Segundo a narrativa do crioulo homicida, ele foi procurar o feiticeiro Tomás para acertar as contas e, inicialmente, apenas pedir seu

54 James H. Sweet, Recriar a África. Cultura, parentesco e religião no mundo afro-português (1441-1770), Lisboa: Edições 70, 2007, p. 212

55 Sweet, Recriar a África, p. 212. Daniela Buono Calainho, Metrópole das mandingas. Religiosidade negra e inquisição portuguesa no Antigo Regime, Rio de Janeiro: Garamond, 2008, pp. 95-6 e 184. Ver também: Eduardo França Paiva, "Celebrando a alforria: amuletos e práticas culturais entre as mulheres negras e mestiças do Brasil”, in István Jancsó, Iris Kantor (orgs.), Festa: cultura e sociabilidade na América Portuguesa (São Paulo: Fapesp, 2001) v..2. Já na costa africana da Guiné, portugueses, lançados e tangomaos contataram e assimilaram hábitos de diversos grupos mandingas que ali viviam. Roger Sansi, "Feitiço e fetiche no Atlântico moderno", Revista de Antropologia, v. 51, n. 1[online] (2008), pp. 123-53, esp. 132. 
dinheiro de volta. Tomás foi encontrado em uma casa da rua 24 de Outubro e os dois saíram caminhando até a venda de Roberto de Tal, onde entraram, e Tomás ofereceu cachaça ao seu futuro carrasco. O oferecimento da cachaça talvez tenha sido uma tentativa do preto mina restabelecer a cumplicidade entre eles, ambos negros e homens, conhecedores da dureza do tráfico e da escravidão. Não aceitar a bebida que lhe oferecem em um espaço público é ofensa gravíssima, estabelece distância, dissonância.

Mas, depois de vários depoimentos em que a história se repetia com pequeníssimas variações, em um dos depoimentos, Antonio informa que, ao saírem inimizados da venda, Tomás parou numa casa vizinha onde conversou com uma preta mina. Tomás, que nesse momento também é identificado como mina, perguntou então a ela se tinha $o b i$ para vender. Aflorava nesse documento uma pista preciosa - obi é uma espécie originária da África, chamado também de "noz de cola, indispensável no cerimonial jeje-nagô (cola acuminata)". ${ }^{56}$ Segundo Nei Lopes, obi é uma

denominação iorubana da coleeira, planta da família das esterculiáceas, produtora do fruto de mesmo nome (noz-de-cola), largamente usado na tradição religiosa afro-brasileira, tanto como objeto de oferenda, como em processos divinatórios. No Brasil, conhecem-se duas espécies: o obi-abatá (cola acuminata), também chamado obi-de-quatro-bandas, e o obi-banjá (cola nítida), de duas. Ao ato de confirmação de um iniciado, mediante a colocação de um obi partido sobre sua cabeça, chama-se "plantar o obi". ${ }^{57}$

Na região do Mali, segundo as memórias de Amadou Hampâté Bâ, ${ }^{58}$ a noz-de-cola era usada também como troca simbólica durante o ritual do casamento, sob o olhar de testemunhas e autoridades religiosas. ${ }^{59}$

${ }^{56}$ Luis da Câmara Cascudo, Dicionário do Folclore Brasileiro, Belo Horizonte / Rio de Janeiro: Editora Itatiaia Limitada, 1988, p. 234.

${ }^{57}$ Nei Lopes, Enciclopédia Brasileira da Diáspora Africana, São Paulo: Selo Negro, 2004, p. 487.

58 Amadou Hampãtè Bâ, Amkoullel, o menino fula. São Paulo: Palas Athena/Casa das Áfricas, 2003, p. 60.

59 O romancista nigeriano Chinua Achebe reiteradamente salienta a importância da noz-de-cola em vários rituais do povo ibo: oferendas aos ancestrais, demonstração de boas-vindas aos parentes e aliados, cerimoniais divinatórios diversos. Ele narra, por exemplo, o caso de um homem conhecido como "curandeiro malvado. Mais de duas vezes fora obrigado a tomar noz-de-cola da palma da mão de um homem morto, para jurar que não tivera nenhuma participação no seu falecimento". Chinua Achebe, A flecha de Deus, São Paulo: Companhia das Letras, 2011, p. 286. 
Talvez o fato de esta pista ter aparecido em apenas um dos depoimentos dado pelo réu, seja um indicativo de que se tratava de algo que as autoridades públicas não tinham ideia e, quando mencionado, não foi compreendido, sendo simplesmente descartado nos autos judiciários. Mas isso aponta a importância dos pretos minas na sociabilidade da diáspora, na reinvenção de identidades étnicas. Os obis devem ter entrado na província sulina via o porto de Rio Grande. Próxima cerca de 65 quilômetros desse porto, a cidade de Pelotas, e principalmente sua população africana ou afrodescendente, facilmente se abastecia da zona portuária. Talvez os obis não viessem diretamente do continente africano, mas certamente os barcos, que vinham de Pernambuco, Salvador e outros portos com relações privilegiadas com a costa da mina, traziam estes produtos religiosos e curativos. Se o cativo Antonio veio da cadeia de Recife para uma charqueada em Pelotas, muito mais facilmente pequenas cargas desses produtos viriam também abastecer a comunidade negra e suas lideranças religiosas minas. ${ }^{60}$

Em plena guerra civil farroupilha, em 1838, as autoridades provinciais receberam uma denúncia anônima alertando-as para a existência de uma "casa que servia aos pretos como de escola onde aprendiam a ler e escrever", em Porto Alegre. A casa em questão foi invadida, os frequentadores e moradores presos e vários textos e dois livros foram apreendidos. Temerosos com a recente tentativa insurrecional dos malês, em 1835, na Bahia, o presidente da província enviou o material para a cidade do Rio Grande. O porto atlântico do Rio Grande dava condições para que as autoridades pudessem examinar com cuidado os documentos escritos em estranhos hieróglifos. A cidade encontrava-se sob o seguro domínio do Império brasileiro e sua população comportava grande número de cativos, e entre eles muitos oriundos da Costa da Mina. As autoridades suspeitavam (ou temiam) que os textos e livros fossem es-

Atualmente, segundo estudos etnobotânicos, a noz-de-cola ou obi continua importante nos cultos afro-brasileiros em várias situações ritualísticas, como nas iniciações, cerimônias especiais (ebós/despachos, celebrações fúnebres), ornamento e proteção das casas e também por suas propriedades curativas (rejuvenesce e diminui a queda de cabelo) e divinatórias; Ulysses Paulino de Albuquerque, "Formas de uso de espécies vegetais nos cultos afro-brasileiros do Recife-Pe", Biologica Brasilica, v. 6, n. 1/2 (1995), pp. 111-20.

${ }^{60}$ Scherer já mostrou a organização e eficácia dos minas na cidade de Rio Grande, em termos da obtenção de alforrias; Jovani de Souza Scherer, "Experiências de busca da liberdade: alforria e comunidade africana em Rio Grande, século XIX” (Dissertação de Mestrado, Unisinos, 2008). 
critos em árabe, e sabiam que muitos africanos procedentes daquela região da África ocidental dominavam essa língua. ${ }^{61}$

Ao longo da investigação, as autoridades chegaram ao preto José, que fora escravo de Manoel José Barreiros e que "sabia ler e escrever segundo o método da costa da Mina". Segundo o seu depoimento, José, ou Muamba (como era chamado na África), tinha então 79 anos, tendo chegado ao Brasil escravizado aos 37 anos. Ele era natural da Costa da Mina, de nação haussá, e morava ainda na casa de seu antigo senhor. $\mathrm{O}$ juiz pediu-lhe "que declarasse quais as rezas e seus significados ou o que queriam dizer na língua de branco?". Respondendo Muamba que "sendo rezas da sua terra e não tendo ele interrogado bastante inteligência da língua nacional, não podia fazer uma perfeita tradução, mas que asseverava, que eram orações de que faziam uso em diversas ocasiões, bem como quando se achavam para morrer".

Recapitulando, o africano José disse ser natural da Costa da Mina, de nação haussá. Os minas eram abundantes na sociedade escravista brasileira, referência a fortaleza de São Jorge da Mina, construída em 1481, que segundo os relatos de época possuiria dois fossos cavados na rocha, 400 canhões e poderia "armazenar" até 1.000 escravos, tendo sido tomada pelos holandeses em 1637. Da Costa da Mina vinham africanos de cultura iorubá, haussá, ashanti etc. Segundo Reis, mina era um "termo geral para designar os escravos oriundos da África ocidental, em particular os embarcados em portos do golfo do Benin". ${ }^{62}$ Autoidentificar-se como mina reforçava sua origem africana, mas somando sua dimensão diaspórica. Ser mina era ser africano na diáspora. Os de nação haussá eram africanos da região do rio Niger, cuja islamização começou no século XIV. Como podemos perceber, Muamba lia e escrevia em árabe, além de certamente conhecer a língua haussá e talvez o iorubá. Como não tinha "bastante inteligência" em português, devia ser integrante de uma ativa comunidade mina naquele porto atlântico, onde exercitava seus costumes, suas línguas nativas e religiões. Os textos apreendidos no Clube mina de Porto Alegre eram escritos em ajami, "língua haussá vertida em letras árabes". ${ }^{3}$

${ }^{61}$ Ofício do Presidente da Província Manoel Joaquim de Souza Medeiros para o Ministro da Justiça Antonio Elzeário de Miranda Brito, 10 de novembro de 1838, Arquivo Nacional do Rio de Janeiro, fundo GIFI, Ministério da Justiça, $3^{\text {a }}$ seção, maço 5C 478.

${ }^{62}$ Reis, Rebelião escrava, p. 285.

${ }^{63}$ Reis et al., $O$ alufá Rufino, p. 62. 
Vários estudos já alertaram sobre os riscos de uma leitura etnicista dos supostos etnômios encontrados, afinal:

As designações dos grupos étnicos indicavam ora a procedência do porto de embarque ou da região genérica de onde eram provenientes, ora um grupo identificado dentro do Brasil, com características, aos olhos dos colonos, semelhantes, ora, ainda, a forma pela qual se autonomeavam. ${ }^{64}$

Tratando da heterogeneidade étnica da escravidão brasileira e também do quanto existia de invenção senhorial na categoria africano, Manolo Florentino investigou o universo das alforrias no Rio de Janeiro, chamando a atenção para a presença dos minas ou afro-ocidentais. A grande presença mina entre os alforriados cariocas pode ser explicada, segundo Florentino, por sua capacidade de acumular recursos e a

força da identidade entre as diversas etnias genericamente agrupadas sob o 'rótulo' mina, expressa na eficiência de instituições que sustentavam a montagem de pecúlios, como as irmandades, as associações de auxílio mútuo, os cantos, a família. ${ }^{65}$

Este investimento mina na sociabilidade e na composição de redes socio-familiares tornava-os mais aptos a acumular capitais pecuniários e relacionais e, consequentemente, ampliar sua autonomia, ainda em cativeiro, e obter a alforria para si e membros de sua extensa família (sanguínea, espiritual, simbólica). Esse fenômeno comportamental parece ter influenciado a construção de representações senhoriais construídas sobre esse grupo: ao mesmo tempo em que o seu espírito coletivo assustava as autoridades com seu potencial subversivo, eram, paralelamente, valorizados enquanto esforçados trabalhadores. Procurando captar o impacto da Lei de 20 de setembro de 1871, o governo imperial expediu um Aviso Ministerial em 1876, pedindo informações às autoridades judiciárias sobre o aumento ou diminuição de crimes após essa lei. O juiz municipal de Rio Pardo, importante município sulino, respondeu ainda mais do que o que lhe foi indagado; segundo Antônio Vicente de Siqueira Pereira Leitão,

${ }^{64}$ Sheila de Castro Faria, "Sinhás pretas, damas mercadoras. As pretas minas nas cidades do Rio de Janeiro e de São João Del Rey (1700-1850)" (Tese apresentada para concurso de professor titular em História do Brasil, Universidade Federal Fluminense, 2004), p. 34.

65 Manolo Florentino, "Sobre minas, crioulos e a liberdade costumeira no Rio de janeiro, 17891871", in Manolo Florentino (org.), Tráfico, cativeiro e liberdade (Rio de Janeiro, séculos XVII-XIX) (Rio de Janeiro: Civilização Brasileira, 2005), pp. 332-66, esp. 353. 
Não consta que na Comarca [de Rio Pardo] houvesse outro crime depois da Lei 2040, a qual no meu fraco alcance tem melhorado os costumes dos senhores no tratamento dos seus escravos, e estes mais pacíficos tem se tornado sem dúvida, pelo aumento da esperança de se libertarem à exemplo de tantas libertações legais frequentes, e até promovidas pelos próprios senhores. Os efeitos salutares da Lei me parecem ainda mais profícuos do que se esperava. Seja me permitido observar a respeito dos libertos: os africanos da Costa da Mina são muito trabalhadores, os [de]mais libertos, quer brasileiros, quer africanos, são mais preguiçosos. ${ }^{66}$

Em 1848, uma insurreição de "negros de nação Mina existentes" em Pelotas, "e nas charqueadas e olarias que lhe são próximas", foi desmantelada, mediante a denúncia de um cativo desta nação. Esse alcaguete, chamado Procópio, foi recompensado com uma alforria, mediante o pagamento pelo governo imperial de 797 mil réis a seu senhor, Luis Manoel Pinto Ribeiro, "por haver o mesmo denunciado uma insurreição, que estava projetada pelos negros de sua nação, os quais denunciou e entregou aquela autoridade que os mandou prender e corrigir". ${ }^{67}$

Analisando a tentativa de fuga, da Bahia, do liberto jeje Sebastião, que devia o dinheiro adiantado por outro forro para a sua liberdade, João José Reis, procurando explicar porque ele pretendia fugir para o Rio Grande do Sul, explana:

Aquela província do extremo sul do Brasil era, ao lado do Rio de Janeiro, o destino de muitos africanos residentes na Bahia, tanto aqueles transportados pelo tráfico interno de escravos quanto libertos que decidiam tentar a sorte noutras regiões do país. Tanto o Rio Grande como o Rio de Janeiro tinham ambos comunidades numerosas de negros minas, sob cujo guarda-chuva étnico se abrigavam naquelas províncias os nagôs, jejes, haussás e outros grupos importados dos portos do golfo do Benim, na costa africana, e que na Bahia assumiam etnônimos mais específicos. ${ }^{68}$

${ }^{66}$ Ofícios da Presidência da Província do RGS dirigidos ao Ministério dos Negócios da Justiça, 1876, Arquivo Nacional do RJ, Série Justiça, Maço IJ603. Ver também: Melina Kleinert Perussato, "Como se de ventre livre nascesse: experiências de cativeiro, parentesco, emancipação e liberdade nos derradeiros anos da escravidão - Rio Pardo/RS, c.1860 - c.1888" (Dissertação de Mestrado, Universidade do Vale do Rio dos Sinos, 2010).

${ }^{67}$ Sílvio Marcus de Souza Corrêa, "Africanos na província de São Pedro (1835-1848): quanto vale a liberdade?", in III Jornada sobre Escravidão e liberdade no Brasil meridional, Florianópolis: 2007, disponível em <http://www.escravidaoeliberdade.com.br/site/images/Textos3/ silvio\%20de\%corres.pdf $>$, acessado em 21 de setembro de 2012

68 João José Reis, Domingos Sodré. Um sacerdote africano: escravidão, liberdade e candomblé na Bahia do século XIX, São Paulo: Companhia das Letras, 2008, p. 260. 
Poderíamos arrolar mais uma série de indícios documentais que atestariam a presença e experiências coletivas dos minas. Antonio identifica a vítima e a preta com quem ele tenta negociar obis como minas, mas não sabemos que aspectos foram importantes nessa identificação. Seriam marcas corporais (de nação), auto-representações, manejo de práticas religiosas e curativas, penteados? Tomás vivia (e talvez tenha se alforriado) dos êxitos de seu talento como feiticeiro e curandeiro, mas padeceu dos percalços inerentes a tal ofício, cujo êxito está ligado umbilicalmente a crença de seus clientes, mas também da repetição de seus sucessos.

Tratando do lugar dos adivinhos na sociedade, o antropólogo EvansPritchar menciona que estes, "quando não estão desempenhando tal função de mágico, sua posição social não é superior à de qualquer outro cidadão comum". Segundo ele, a fama do adivinho não se esgota no conhecimento restrito da arte da adivinhação e do curandeirismo, "seu prestígio depende menos da prática do ofício em si que de sua reputação pessoal ao desempenhá-lo". ${ }^{69}$ Isso faz com que não seja fácil um feiticeiro manter sua posição, já que a crença em seus poderes depende da eficácia de suas ações. Afinal, os crentes "temperam a fé com ceticismo".

Mesmo que os feiticeiros ou curandeiros que tenhamos encontrado até agora não vivessem unicamente de suas artes específicas, isso não indica que não possuíssem uma especialização social, pela qual recebiam retribuições pecuniárias de diferentes suportes: dinheiro, alimentos, ferramentas etc. Conforme argumenta Evans-Pritchard com relação aos adivinhos azande, os indivíduos que exerciam e eram aceitos pela comunidade como curadores, possuíam características psicológicas que os diferenciavam da mentalidade de um leigo:

Como sabemos que os adivinhos têm consciência de uma parte da realidade inacessível ao resto da sociedade, poderíamos nos perguntar se eles não possuem igualmente uma apreciação mais ampla da natureza de outras coisas no mundo que os cerca. Não cheguei a tal conclusão. Mas nunca deixei de ficar impressionado com a habilidade deles, e penso que, quando se conhece bem os Azande, é possível detectar o mágico esperto, especialmente o adivinho bem-sucedido. Não tenho provas suficientes para demonstrá-lo, mas considero provável que os homens que

${ }^{69}$ Edward Evans-Pritchard, Bruxaria, oráculos e magia entre os azande. Rio de Janeiro: Jorge Zahar, 2005, pp. 129-30. 
desejam tornar-se adivinhos possuem, em geral, um grau mais elevado de curiosidade intelectual e de ambição social que o Azande comum. Sua personalidade é certamente desenvolvida pelos novos modelos de comportamento social próprios da profissão, que exigem tato, coragem, clarividência, conhecimento das emoções humanas e uma agilidade mental consideráveis, requisitos fundamentais para o sucesso de sua atividade. Não tenho dúvidas, a julgar pelos adivinhos que conheci pessoalmente, que eles demonstram maior habilidade que a maioria dos leigos; isso pode ser visto não somente em seu comportamento ritual, mas também na competência genérica no relacionamento social, na compreensão rápida de situações novas, no conhecimento da tradição, no saber econômico e no poder de impressionar e dirigir os homens. ${ }^{70}$

A posição de feiticeiro ou curandeiro demanda que estes tenham algumas características inerentes aos ofícios que pretendem desempenhar. Certa dose de vaidade pessoal, uma ótima leitura dos comportamentos alheios, que certamente ajudava no contato com os senhores e parceiros em geral. Isso pode ser verificado, por exemplo, ao vermos como vários curandeiros ou feiticeiros conseguiram obter alforria. Outrossim, pelas declarações conscientes de alguns destes, quando foram a tribunal. Em novembro de 1871, o curandeiro Joaquim Mina foi preso e processado em Porto Alegre, por tentar envenenar alguns desafetos, seduzindo as criadas da casa e propinando substâncias cáusticas na comida e bebida de uma família branca da capital. Joaquim se alforriara seis anos antes e circulava pela cidade ocupado em serviços diversos, mas principalmente vendendo preparados para acalmar senhores e mulheres. No tribunal, Joaquim insistiu que estava "sofrendo inocentemente", mas alegou que não tinha testemunha alguma a apresentar para "provar ou alegar" a sua inocência, pois "sempre morou com companheiros pretos, mas que testemunhos de preto não servem". ${ }^{71}$

${ }^{70}$ Evans-Pritchard, Bruxaria, oráculos e magia entre os azande, pp. 133-4.

71 Roger Costa da Silva, Muzungas: consumo e manuseio de químicas por escravos e libertos no Rio. Grande do Sul (1828 - 1888), Pelotas: EDUCAT, 2001; Paulo Roberto Staudt Moreira, "Feiticeiros, venenos e batuques: religiosidade negra no espaço urbano (Porto Alegre - século XIX)", in Luiz Alberto Grijó, Fábio Kuhn, César A. Barcellos Guazzelli, Eduardo Santos Neumann (orgs.), Capítulos de História do Rio Grande do Sul (Porto Alegre: Ed UFRGS, 2004), p. 14777. Aliás, Joaquim Mina ou Joaquim da Cunha Vieira, acabou sendo inocentado no tribunal, e na noite em que os jurados passaram fechados no tribunal decidindo o seu destino, os vereadores escutaram assustados os tambores ecoando por Porto Alegre. A comunidade negra local informava pelos meios tradicionais que estava atenta ao que transcorria. 
Mas qual o preço de uma mandinga? O pernambucano Antonio nos informa que pagou três mil réis ao mina Tomás, por um patuá que o amparasse no confronto diário com o capataz e o administrador. Mas qual o valor de um instrumento desses no mercado da crença oitocentista? Vejamos.

Naquele mesmo ano de 1879, em 9 de junho, faleceu em Porto Alegre o preto forro Bento da Costa, que precavidamente havia em janeiro daquele ano, certamente sentindo que as forças vitais se exauriam, redigido um testamento. ${ }^{72}$ Bento era legitimamente casado com Maria Cecilia Ricarda, ambos eram nagôs, libertos, frequentavam o catolicismo e não tinham filhos. Maria Cecilia alforriou-se em abril de 1863, com o auxílio de seu companheiro, pagando 1 conto e oitocentos mil réis a sua senhora Ricarda Antonia de Menezes. ${ }^{73}$ Bento conseguiu alforriar-se 5 anos antes de sua companheira, com a condição de dar a mesma senhora um escravo "igual a ele ou o valor de 1:800\$ réis para outro escravo a meu contento". ${ }^{74} \mathrm{O}$ patrimônio imaterial desse casal de africanos forros é inestimável, já que não se pode avaliar o quanto valia simbólica e psicologicamente livrar-se do cativeiro, morar sobre si em uma residência própria e esperar o findamento ao lado de uma companheira da mesma nação africana. Mas, pelo inventário, percebemos que o patrimônio material que reuniram valia $28 \%$ do capital que despenderam para a alforria de ambos. Os avaliadores estimaram que a casa em que habitavam, no antigo Beco do Poço, e os móveis da mesma, valiam um conto e 25 mil réis. Entre os utensílios da casa, o "trem de cozinha" valia exatamente o preço da mandinga mina, três mil réis, enquanto um baú velho era estimado em $1 \$$; a louça a uso em $\$ 400$; um banco de pau, \$500; uma mesa velha, $1 \$$; um talha velha, \$400.

Tanto em Pelotas, como em Porto Alegre, a quantia gasta por Antonio ao adquirir o patuá, equivalia ao valor de alguns poucos bens. $\mathrm{Na}$ verdade, sondando os dados que possuímos sobre os mundos do trabalho sul-rio-grandense, 3 mil réis seriam o equivalente a um ou dois dias de jornal de um trabalhador braçal urbano semi-especializado. Um mestre de ofício ganharia um pouco mais. Essa especulação é confirmada pelas

72 Inventários, APERS, Cartório da Provedoria, nº 528 e 2022, maço 30 e 70.

${ }^{73}$ Carta de Alforria, 9 de abril de 1863, APERS, Livros do $1^{\circ}$ Tabelionato de Porto Alegre Registros Diversos $\mathrm{n}^{\circ}$ 17, folha 133v.

${ }^{74}$ Carta de Alforria, 19 de julho de 1858, APERS - Livros do $1^{\circ}$ Tabelionato de Porto Alegre Registros Diversos $\mathrm{n}^{\circ}$ 4, folha $17 \mathrm{v}$. 
pesquisas do historiador João José Reis para a Bahia, que informa que no mercado espiritual de Salvador, um amuleto custava cerca de 320 réis, "cifra próxima da diária paga aos senhores em torno de 1835". 75

Ou seja, era um investimento possível de ser feito por um popular oitocentista, mas certamente demandava um cálculo prévio, principalmente por trabalhadores escravos como Antonio, que não deviam ter muitos dias para trabalhar para si e acumular algum pecúlio. Mas mandingas, como as comercializadas pelo preto mina Tomás, agregavam valor simbólico e utilitário. Portar a mandinga era assumir a cumplicidade de pertencimento a uma cultura afro-brasileira. Era um investimento cotidiano na existência de uma identidade que unia os clientes daquele e de outros feiticeiros, que compartilhavam a crença de que os patuás dariam segurança espiritual e psicológica aos seus portadores, impedindo (ou atenuando) os desmandos senhoriais. O sucesso dos africanos minas em alforriar-se, estando mais representados entre os libertandos do que na população como um todo, pode estar ligado a essas lideranças religiosas. ${ }^{76}$ A competência dos minas em reunir em torno de si adeptos às suas práticas religiosas e curativas, deve ter sido um importante atrativo. Situados no centro do guarda-chuva étnico mina, esses curandeiros devem ter funcionado como atrativos para outros africanos, que não hesitaram em se autodefinir como minas, já que compartilhavam valores ligados ao natural e ao sobrenatural.

Aqui pensamos nas construções das 'nações' angola, moçambique, cabinda, benguela, congo, mina e tantas outras numa perspectiva transétnica. Ainda que quase todas sejam genéricas, algumas podem ter sido consideradas como identidades de abrangência mais ampla - nos termos de ' guarda-chuva étnico' [...] Estariam então essas nações sendo formadas num movimento transétnico de permanente transformação pelas mudanças e lógicas culturais das reinvenções da África em espaços específicos da diáspora. ${ }^{77}$

75 Reis, Rebelião escrava no Brasil, p. 380.

76 Scherer, Experiências de busca da liberdade, p. 121; Florentino, "Sobre minas, crioulos e a liberdade costumeira, pp. 331-66, esp. 352.

77 Carlos Eugênio Líbano Soares, Flavio Gomes, Juliana Barreto Farias Gomes, No labirinto das nações: africanos e identidades no Rio de Janeiro, Rio de Janeiro: Arquivo Nacional, 2005, p. 50. Ver também João José Reis, "Identidade e diversidades étnicas nas irmandades negras no tempo da escravidão", Tempo, v. 2, n. 3 (1997), pp. 7-22, esp. 9. Sobre as reinvenções étnicas, ver também: Robert W. Slenes, "Malungu, ngoma vem!" África encoberta e descoberta no Brasil. Cadernos da escravatura (1995). 
Pelos indícios judiciários não parece que Antonio quisesse esconder suas intenções e fugir à responsabilidade do assassinato. Manejando o instrumento da arte de seu ofício de carneador, ele assassinou o preto mina sem cogitar que ele sobrevivesse - duas facadas certeiras e uma última, com a vítima já no solo, para sanar qualquer dúvida. Talvez o cativeiro na charqueada fosse excessivamente duro, ainda mais com a implicância do administrador e Antonio tenha agido com consciência da radical mudança que sua existência sofreria.

Numa terça-feira, 18 de março de 1879, o porteiro João Maria Braga tocou a campainha comunicando o início dos trabalhos na Casa da Câmara de Pelotas. O crioulo pernambucano Antonio teve então a última chance de deixar registrada a sua versão sobre o ocorrido. Ele assumiu o assassinado, dizendo que Tomás "merecia, porque não sabia fazer nada, e andava enganando a humanidade, assim como o enganou em 3 mil réis e ainda foi contar a seu senhor o que ele tinha mandado fazer, e assim matando-o ele não enganava a mais ninguém". Ele admitiu que "pretendia matar o administrador, mas a desgraça deu-lhe para matar o preto Tomás". Foram duas facadas com o preto de pé, e depois já caído, "como não estivesse bem morto, deu-lhe terceira e limpando a faca apresentou-se ao delegado de polícia". Nesse derradeiro gesto antes de ser preso, o carneador não resiste e automaticamente limpa a faca - quem precisa dela como ferramenta de trabalho, sabe que o sangue estraga o seu fio.

O júri não se demorou muito em deliberar. Por unanimidade decidiram que o réu fez os ferimentos, de que destes ferimentos resultou a morte, que foi por motivo frívolo, com superioridade de forças, de surpresa, que houve premeditação, que não existiam circunstâncias atenuantes. Livrava-se, então, Antonio, do cativeiro no qual nasceu, recebendo a pena de galés perpétuas, confirmada pelo Tribunal de Relação de Porto Alegre em 12 de maio de 1882.

\section{Por questão de nonada}

Em seu Relatório de 1897, o médico Sebastião Affonso de Leão informava que existiam na Casa de Correção da capital da província 226 presos. Influenciado pelas mais recentes teorias criminológicas da época, de Lombroso a Lacassaigne, o dr. Leão legou-nos um texto que descreve os presos nas suas características mais diversas, físicas, comportamentais, 
profissionais. O médico da polícia dr. Leão, em um segmento de seu relatório, dirigido ao Secretário de Estado dos Negócios do Interior, menciona dois prisioneiros por serem os "de maior idade":

José Roberto Pinheiro, que, aos 64 anos de idade, em companhia de dois filhos (um dos quais menor), degola um inofensivo velho para roubá-lo, e o preto Antônio Rasgado, que, em Pelotas, no dia 15 de Janeiro de 1879, contando 69 anos de idade, mata a facadas um capataz da estância, que o espancava barbaramente, por questão de nonada (fotografia n. ${ }^{0} 95$ ). ${ }^{78}$

A indicação da fotografia, infelizmente, é frustrante. $\mathrm{O}$ dr. Leão montou um laboratório antropométrico e fotografou os prisioneiros da Casa de Correção de Porto Alegre, sendo Antonio Rasgado um dos eternizados. Infelizmente, o álbum em seu estado atual, não possui várias das fotos originais, sendo uma das faltantes a do nosso personagem principal. ${ }^{79}$

$\mathrm{O}$ dr. Leão nos fornece dois dados surpreendentes, que julgamos que ele obteve conversando com o ex-escravo Antonio. Primeiro, que ele, no momento do crime, tinha 69 e não os 40 que julgaram que ele representava, estando com 87 anos em 1897. Outra coisa é que ao dr. Leão o prisioneiro contou que matara um capataz da estância que o espancava barbaramente, por questão de nonada, "insignificância, bagatela, ninharia".

Por ofício de 17 de fevereiro de 1900, o advogado Carlos F. de Moura Cunha pediu às autoridades judiciárias que o preso Antonio, condenado a galés, e que se encontrava na prisão de Porto Alegre, fosse levado a novo julgamento por não existir mais a pena de galés perpétuas no novo Código Penal aprovado em 1890.

O suplicante foi compelido ao crime, pelo temor de bárbaros castigos, cuja ameaça lhe fora feita, castigos esses mais de uma vez já sofridos, pois eram frequentemente aplicados aos escravos, na charqueada de seu ex-senhor, e pelas mais leves faltas. ${ }^{80}$

78 Moreira, Entre o deboche e a rapina.,

79 Em 5 de março de 1895 o chimango e Chefe de Polícia Borges de Medeiros criou na sua repartição um Gabinete Médico-Legal, aos cuidados dos drs. Sebastião Leão e João Damasceno Ferreira.

${ }^{80}$ O delegado de Polícia de Pelotas, na véspera do natal de 1870, narrou ao chefe de Polícia que um grupo de escravos da charqueada do major Joaquim Rasgado, receosos de castigos de seu senhor ou capataz, passou pela cidade. Os sete cabeças do movimento foram presos, conduzidos até a cadeia civil e moderadamente castigados. Helga L. Piccolo, "A resistência escrava no Rio Grande do Sul”, Cadernos de Estudos, n. 6 (1991), p. 51; Ofício de 23 de dezembro de 1870, AHRS, fundo Delegacia de Polícia, maço 10. 
Segundo o advogado, o júri não reconheceu esta circunstância atenuante, marcada no Artigo 41, parágrafo 7 do Código Penal atual: ${ }^{81}$

Essa ameaça de castigos bárbaros sofridos muitas vezes pelo suplicante e seus infelizes companheiros de cativeiro, acha-se provada não só no processo do suplicante, como ainda no do preto Caetano, também Exescravo do Coronel Rasgado, compelido ao crime pelo mesmo motivo, e da mesma sorte condenado. ${ }^{82} \mathrm{O}$ suplicante tem mais de 60 anos de idade, e vinte de prisão, tendo sempre revelado exemplar procedimento, como vê-se do documento incluso.

O documento anexo é do administrador em comissão da Casa de Correção da capital, Ernesto Th. Jaeger:

Atesto, em virtude do despacho retro, que o peticionário acha-se preso neste estabelecimento há 18 anos, tendo tido sempre excelente comportamento, pelo que tem gozado da estima e confiança de seus superiores. Casa de Correção em Porto Alegre 16 de fevereiro de 1890.

O desembargador procurador geral do Estado achou aplicável neste caso o artigo $3^{\circ}$ do Código Penal e a pena passou para 24 anos de prisão celular. Essa foi a última informação que tivemos do pernambucano Antonio Rasgado. Se tinha 87 anos em 1897, teria 90 em 1900, ainda faltando seis anos de confinamento.

\section{Entendeu que Tomás deveria ser o sacrificado, já que a desgraça assim queria}

Segundo João José Reis, negociar e consumir utensílios diversos para amansar os senhores é parte de uma bagagem cultural de remota existência no Brasil: "A farmacopeia nagô-iorubá [...] é riquíssima em folhas tanto para ataque quanto para proteção, para beneficiar e prejudicar, cujo uso deve, em tese, vir acompanhado de encantações pronunciadas pelo babalaô", ${ }^{83}$

${ }^{81}$ Moura errou o artigo, é no $42, \S 7^{\circ}$ que consta: "ter o delinquente cometido o crime impelido por ameaças ou constrangimento físico invencível".

82 Réu: Caetano, solteiro, preto, 20/25 anos, de Santa Catarina, carneador/cozinheiro, filho de Sertório e Maria, escravo do tenente coronel Joaquim Rasgado. Caetano apunhalou às 21 horas de 11 fevereiro de 1882 Celestino Marques Lisboa, praça de policia particular, que faleceu. Foi preso em flagrante. Processo crime, 1882, APERS, Vara Cível e Crime de Pelotas, $n^{\circ}$ 264; Códice de Polícia, AHRS, nº 95.

83 Reis, Domingos Sodré, p. 152. 
Ficamos indagando que, se Antonio ainda fosse cozinheiro, teria optado pelas poções, ervas, raízes, que, aliadas a encantamentos, poderia ministrar sub-repticiamente na comida de senhores, seus familiares e capatazes. Como no momento se ocupava de carnear, teve que optar por um patuá que, trazido junto ao corpo, o imunizasse dos desmandos senhoriais e de seus algozes imediatos.

Mas ele não tinha como manejar por si as relações com o oculto e a construção de um utensilio tão complexo, assim teve de recorrer a um especialista - o feiticeiro Tomás Soares, liberto. Analisando o mundo do candomblé oitocentista baiano, Reis informa que neste círculo mandavam os libertos, pois eles "tinham os recursos materiais e a mobilidade social necessárias para organizar e usufruir a experiência ritual com maior autonomia, apesar das pressões que sofriam das autoridades e da sociedade". ${ }^{84}$

Reconhecendo os hibridismos e ressignificações identitárias que ocorriam quando da diáspora africana, o historiador Rossel-Wood chama a atenção de que a individualidade de sua herança, a sua consciência africana, era preservada e, principalmente quando alforriados, os africanos manifestavam com ênfase suas etnicidades, criando, por exemplo, locais de reunião dos negros de sua nação. ${ }^{85}$ É arriscado e prematuro supor para que uso Tomás Soares queria obi/noz-de-cola, que procurou comprar de pretas, minas como ele, naquele fatídico dia. Sabemos que ele comercializava mandingas e isso nos faz pressupor que, tal como o indivíduo biografado por João José Reis, fosse feiticeiro e adivinho - "ou seja, além de adivinhar, ele fazia outros trabalhos de monitoramento e manipulação do universo espiritual. Uma atividade estava estreitamente vinculada a outra, pois quem adivinha um problema deve saber adivinhar a sua solução" " Assim, sua presença é um indício importante de identidades africanas diasporicas, antes não bem estudadas no Brasil meridional.

Investigando "os povos africanos e as culturas que estes criaram no contexto do mundo colonial português entre 1441 e1770", James Sweet chama a atenção para a similaridade que existia entre rituais de adivinhação da África Central e Ocidental:

${ }^{84}$ Reis, Domingos Sodré, p. 271.

85 A. J. R. Russell-Wood, Escravos e libertos no Brasil colonial, Rio de Janeiro: Civilização Brasileira, 2005, p. 171.

${ }^{86}$ Reis, Domingos Sodré, p.132. 
existiam alguns rituais que, na sua semelhança, transcendiam as diferenças étnicas e os espaços geográficos. É provável que estes rituais mais abrangentes tenham facilitado o processo de crioulização entre africanos de diversos contextos étnicos, levando à criação de formas marcadamente 'africanas' de cultura escrava. ${ }^{87}$

Mesmo que as maneiras e os rituais fossem díspares, "os fins eram sempre os mesmos - a restauração do equilíbrio temporal através da intervenção espiritual". ${ }^{88}$

Uma destas "categorias de crença de adivinhação partilhadas entre os africanos da diáspora era o augúrio, ou adivinhação através de presságios". Mesmo acanhados sinais poderiam ser interpretados como indícios de desequilíbrios e prenúncio de maus ou bons prognósticos. Danificar duas vezes o couro da rês durante a extração diária, ver negado o segundo apadrinhamento pedido, perceber que a proteção adquirida de um seu líder espiritual fracassara e ainda ter passado, não se sabe quando, de cozinheiro para carneador, podem ter sido interpretados por Antonio como de desventura e desequilíbrio. Realmente, o cativeiro de Antonio, sua força espiritual, seu axé, não estavam bons. Talvez a morte de Tomás Soares - o seu sacrifício - significasse uma tentativa de Antonio restabelecer o equilíbrio, já que, como declarou em juízo, "andava com a cabeça incomodada por seu cativeiro". A destreza de seu braço, que falhara duas vezes e tornara-o vulnerável à vingança do administrador, não lhe faltou no justiçamento do feiticeiro. Notem-se aí a sutileza e os riscos envolvidos quando um indivíduo assumia a posição de feiticeiro.

Os vestígios da existência destes personagens, imortalizados nas páginas judiciárias, nos faz pensar na potencialidade destes documentos para a pesquisa história. Os processos criminais são observatórios que permitem uma percepção das hierarquias dos lugares, dando um retrato momentâneo que congelava ilustrativamente as parcerias e os desentendimentos. As tramas sociais não são apenas de solidariedades e alianças, mas são redes complexas de intrigas e desavenças, cumplicidades e traições. Claro que o acontecimento não se esgota em si mesmo, necessitando um movimento reducionista e ampliador de escalas,

\footnotetext{
${ }^{87}$ Sweet, Recriar a África, p. 16 e 158.

88 Sweet, Recriar a África, p. 160.
} 
para que percebamos as múltiplas variáveis (regionais, nacionais, internacionais) em que estavam inseridos os seus atores.

Além disto, os processos criminais nos trazem fragmentos de diálogos, onde detalhes aparentemente irrisórios podem ser aproveitados por uma leitura etnográfica da fonte. O consumo e circulação de obi (noz-de-cola), a comercialização de mandingas, a participação privilegiada de curandeiros e feiticeiros minas no centro de um guarda-chuva étnico, mostra como a diáspora transatlântica fomentou arranjos e reinvenções étnicas nas comunidades africanas do Novo Mundo.

Texto apresentado em 7 de fevereiro de 2012 e aceito em 22 de julho de 2012

\begin{abstract}
Resumo
Numa quarta-feira, 15 de janeiro de 1879, um escravo natural da província de Pernambuco e trabalhador em uma charqueada em Pelotas/RS, assassinou a facadas um africano liberto (de nação mina), famigerado feiticeiro e que comercializava mandingas. Casos coletados das páginas de documentos judiciários envolvendo feiticeiros são ótimos observatórios da sociedade escravista em sua miudeza relacional. Esse artigo, partindo de uma análise de caso, estuda o campo de possibilidades relacionais no qual estavam inseridos ativamente os cativos, mesmo que de estabelecimentos penitenciários como as charqueadas. Além disso, essa pista judiciária nos permite uma aproximação com o mercado da crença e o papel dos feiticeiros/curandeiros na sociabilidade e conformação de identidades etnossociais.
\end{abstract}

Palavras-chaves: escravidão - feitiçaria - etnicidade - hierarquias sociais documentos judiciários.

\begin{abstract}
On Wednesday, January 15, 1879, a slave born in the province of Pernambuco and who worked making salted meat in Pelotas, Rio Grande do Sul, stabbed to death a freed African (of the Mina nation) who was renowned as a sorcerer and amulet maker. Court cases involving sorcerers provide windows into slave society in intimate detail. This article, based on an analysis of case studies, examines the relational field of possibilities in which captives lived, whether they were in prison or at work making salted meat. This kind of documentation also allows us to come closer to the market of beliefs and the role of sorcerers/ healers in sociability and in contouring ethnic and social identity.
\end{abstract}

Keywords: slavery - sorcery-ethnicity - social hierarchies - court documents 